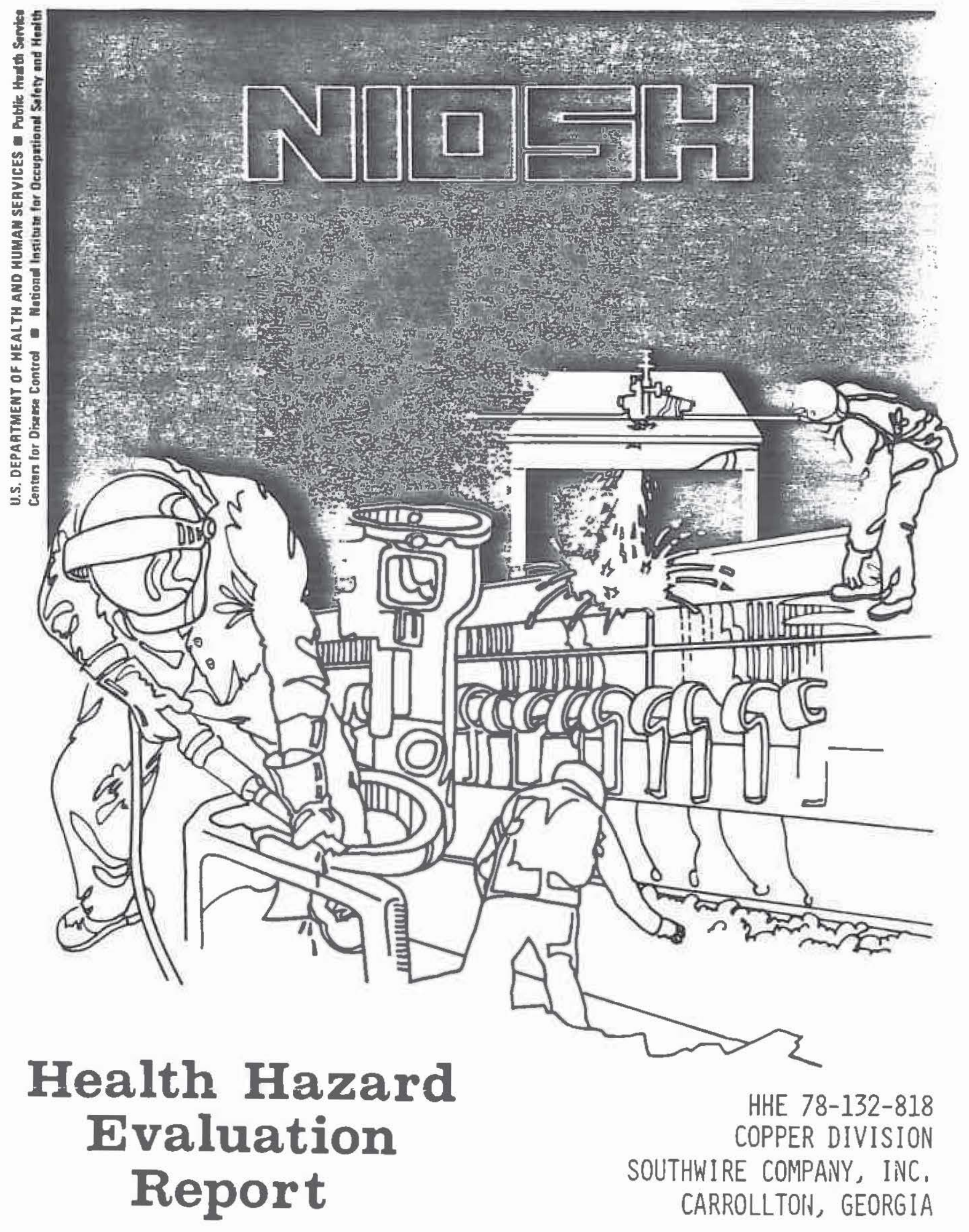




\section{PREFACE}

The Hazard Evaluations and Technical Assistance Branch of NIOSH conducts field investigations of possidle health hazards in the workplace. These Investigations are conducted under the authority of Section $20(a)(6)$ of the Occupational Safety and health Act of 1970, 29 U.S.C. 699(a)(6), which authorizes the Secretary of Health and Human Services, following a written request from any employer or authorized representative of employees, to determine whether any substance normally found in the place of employment has potentially toxic effects in such concentrations as used or found.

Mention of company names or products does not constitute endorsement by the National Institute for Occupational Safety and Health. 
HHE 78-132-818

February 1981

Copper Division

Southwire Company, Inc.

Carrollton, Georgia
NIOSH INVESTIGATORS: John R. Kominsky, I.H. Kathleen Kreiss, M.O.

\section{SUMMARY}

On October 2-11, 1978, a health hazard evaluation was conducted by the National Institute for Occupational Safety and Health (NIOSH) at Southwire Company in Carrollton, Georgia, a secondary copper smelter, to evaluate possible heavy metal poisoning. Personal and area air samples were obtained to measure lead, copper, nickel, cadmium, arsenic, zinc, carbon monoxide, and sulfuric acid concentrations. The medical evaluation included an intervieweradministered medical questionnaire, measurement of blood pressure, neurological examination, and blood tests for lead, copper, zinc, and biochemical and hematologic parameters.

Lead concentrations in $10(21 \%)$ of 47 personal air samples exceeded the previous OSHA standard of $200 \mathrm{ug} / \mathrm{m}^{3}$ and 37 (79\%) exceeded the new OSHA standard of $50 \mathrm{ug} / \mathrm{m}^{3}$. Copper fume concentrations in $13(100 \%)$ samples exceeded the OSHA standard of $100 \mathrm{ug} / \mathrm{m}^{3}$; copper dusts concentrations in 8 (24\%) of 34 samples exceeded the OSHA standard of $1000 \mathrm{ug} / \mathrm{m}^{3}$. Nickel concentrations in 5 (10\%) of 47 samples exceeded the NIOSH recommended standard of $15 \mathrm{ug} / \mathrm{m}^{3}$. Arsenic concentrations in $2(20 \%)$ of 10 samples exceeded the NIOSH rcommended standard of $2 \mathrm{ug} / \mathrm{m}^{3}$. Cadmium concentrations in $?(2 \%)$ of 47 samples exceeded the $\mathrm{N} I O S H$ recommended standard of $40 \mathrm{ug} / \mathrm{M}^{3}$. No excessive exposures were found for zinc, cadmium, carbon monoxide and sulfuric acid.

The medical evaluation involved 293 workers. Employees in the high lead exposure areas have a statistically significant increase of gastrointestinal symptoms, non-specif ic fatigue and weakness, hand tremor, joint pain, and throat irritation. In addition, employees in the dustiest work areas had an increased prevalence of respiratory symptoms such as chronic phlegm production, wheezing, and morning cough. The prevalence of hypertension (38\%) among male Copper Division employees was significantly $(p=0.01)$ greater than the age, sex, and race-adjusted U.S. rates, but there was no clear association with blood lead level or with metal dust exposures. Decreased Achilles tendon reflex and impaired rapid alternating movements were significantly more prevalent (26\% and $22 \%$, respectively) in workers with lead levels over $60 \mathrm{ug} / \mathrm{dl}$ than in those with lead levels $\leq 60$ ug/di (9.3\% and 4.2\%, respectively). Both blood lead and erythrocyte protoporphyrin levels were associated $(r=0.73)$ with metal dust exposure. Seven workers had elevated serum copper levels and nine had elevated serum zinc levels, but these were not associated with either dust exposure or symptoms. The high and intenmediate lead exposure groups had significantly higher mean serum creatinine $(1.19 \mathrm{~g} \%)$ than the low lead exposure group (1.14 g\%), ( $p<.04)$.

On the basis of the environmental and medical findings, NIOSH concluded that a serious hazard of exposure to airborne dust and fume of lead, copper, arsenic and nickel existed at the Copper Division, Southwire Company, Inc., Carrollton, Georgia. Recommendations to control these hazards are made in Section VII. KEYWOROS: SIC 3340 (Secondary Smeiting and Refining of Nonferrous Metals and Alloys), lead, copper, nickel, arsenic and toxic. 
Page 2 - Health Hazard Evaluation Report HE 78-132

\section{INTRODUETION}

Under the Occupational Safety and Health Act of 1970, the National Institute for Occupational Safety and Health (NIOSH) is authorized to investigate toxic effects of substances found in the workplace. In August of 1978 the Division of Physical Health, Department of Human Resources, State of Georgia requested technical assistance from NIOSH to investigate occupational illness among workers employed at the Copper Division of Southwire, Southwire Company, Inc., Carrollton, Georgia. Preliminary inquiry by State of Georgia personnel had indicated that workers were being exposed to toxic concentrations of lead, copper, cadmium and possibly other heavy metals. Subsequently, on September 11,1978 , NIOSH received a health hazard evaluation request from an authorized representative of employees of the Copper Division of Southwire to determine if the employees were being exposed to toxic concentrations of chemicals in their workplace. The request alleged that workers were experiencing health effects including "breathing problems, heart attacks, high blood pressure, shaking hands, nausea, dizziness, headaches and high blood lead." Consequently, the investigation was conducted as a health hazard evaluation and a cooperative working relationship was maintained between NIOSH and State of Georgia investigators.

The environmental-medical investigation was conducted by NIOSH and State of Georgia investigators during 0ctober $2-11,1978$. The results of the investigation were reported to both national and regional representatives of the Occupational Safety and Health Administration resulting in a January 1979 compliance inspection of this facility by OSHA.

\section{BACKGROUNB}

The Copper Division of Southwire is a secondary copper refinery employing approximately 300 persons. The refinery processes both low grade and high grade materials to cathode plates containing $99.99 \%$ elemental copper for internal consumption by the Southwire continuous rod system.

The recoverable scrap is treated by one of two smelting routes, depending on its grade classification. High grade scrap (such as wire, tubing, sheet, etc.) is assayed by the Sampling Department, sorted, compacted into bales, and stored for later use or taken to the anode furnace (known as the Maerz furnace) for direct re-melt and processing.

Lower grades of copper-bearing materials are processed through a standard water-jacketed secondary blast furnace for production of black copper; black copper contains 75 to $85 \%$ elemental copper. (The low-grade copper-bearing materials, including insulated wire and cable, copper fines, and baghouse dust are blended in the bedyard* for charge into the blast furnace.) The black

ॠBedyard Brick Plant - Copper fines from the furnace dust collection systems are combined with a hydrated silicate bonding agent and mechanically compacted to form bricks. These metal alloy-containing bricks are either marketed or either reintroduced to the smelting process. 
Page 3 - Health Hazard Evaluation Report HE 78-132

copper is further treated by blowing with air in a Hoboken syphon converter furnace. Air is forced through tuyeres in the sides of the converter into the molten black copper, producing blister copper containing approximately $96 \%$ elemental copper. The blister copper is then charged to the Maerz furnace. The Maerz furnace further refines the alloy by removing remaining impurities by fire-refining, followed by deoxidation and ultimate casting of the anodes for electrolytic purification.

The Maerz furnace is a 350-ton tilting reverberatory furnace which rolls to -5 degrees from horizontal for 51 ag removal and +25 degrees during the casting cycle. The furnace is charged by two gas/oil burners. It's exit gases are treated in two waste heat boilers. The operation to produce anode copper consists of melting the charge if cold blister is the feed, or transferring the molten copper from the converter by ladle. The molten metal is oxidized by blowing air through iron pipes into the charge. The oxidation phase proceeds until the oxide content approaches 1\% during which time slag may be skimmed as many as three times, depending on the impurities present. This slag is usually returned to the low grade operation. The final phase of processing is deoxidation of the molten metal. Liquid ammonia is the primary reducing agent used, though some green hardwood logs are also charged at the same time to help agitate the molten metal. Once the desired oxygen content and temperature of the molten metal is obtained, the heat is ready for casting. The casting of anodes is performed on a Mitsubishi casting wheel. Copper at about 2050 of is tapped from the furnace into a hydraulically controlled ladle, which is the reservoir for the metal between each pour. The casting wheel holds twenty-four copper molds that have been sprayed with graphite serving as a parting agent. A block insert in each mold allows easy separation of the anode from the mold. The freshly cast anodes undergo a cooling phase via high-pressure water spray to solidify the anode, which is then transported to a yard for temporary storage. The anode ultimately undergoes electrorefining, yielding electrolytic grade copper, via standard ion exchange procedures.

The electrorefining facility consists of three main sections.

1. Tank House: The tank house consists of hundreds of cells arranged in electrical circuits and provided with a piping system to distribute the copper sulfate and sulfuric acid electrolyte. The anodes and cathodes are charged to these cells by overhead cranes. (The cathodes are thin sheets of copper, called "starting sheets", which are produced in a special stripper section of the tank house). The copper of the impure anode is dissolved electrolytical$l y$, and copper migrates to and is deposited at the cathode. Electrolysis continues until the anode is corroded to about $15 \%$ of its original weight, during which time several crops of cathodes are pulled. At the completion of the anode cycle (about twenty-eight days) the anode scrap is washed free of adhering slime, pulled by overhead crane, and transferred to the anode furnace for melting and casting into anodes. The impurities in the anode copper either dissolve in the electrolyte or fall to the bottom of the cells as slime. The impurities include lead, arsenic, gold, silver, antimony, nickel, bismuth, selenium, tellurium and other metals. 


\section{Page 4 - Health Hazard Evaluation Report HE 78-132}

2. Electrolyte Purification: The impurity level in the electrolyte is of paramount importance in determining the impurity composition of the cathode copper. The electrolyte purification operation is performed for the purpose of controlling the concentration of copper and of soluble impurities. This is achieved by electrolysis in "liberator cells" employing insoluble lead anodes. (The crude nickel sulfate produced is washed and dewatered in a centrifuge, dried, packaged, and marketed).

3. Slime treatment: The insoluble metals and compounds that settle to the bottom of the tanks during the electrolytic cycle are screened and pumped to a slime-treatment (or "anode mud") plant. Here the slime is dewatered, dried, packaged, assayed and marketed.

\section{STUDY OESIGN AND METHCDS}

A walk-through survey was conducted at the Copper Division of Southwire on September 22, 1978. Background information about processes, materials, work practices, environmental controls, and employee profiles were obtained.

Subsequently, the environmental evaluation was conducted on October 2-6, 1978; the medical evaluation was conducted 0ctober 4-6, 10 and $11,1978$.

\section{A. Environmental}

The environmental protocol was designed with emphasis on evaluating and characterizing exposures related to the smelting process. Secondary emphasis was directed at the electrorefining operations. The smelting process was subdivided into seven exposure areas to facilitate environmental sampling: (1) Bedyard - low grade copper bearing materials handling. (2) Bedyard brick plant. (3) Baghouse. (4) Sampling department. (5) Blast and converter furnace. (6) Maerz furnace tear-down. (7) Cleaning of the Maerz furnace waste-heat boiler (known as the economizer). The workers involved in these areas were evaluated regarding their exposures to inorganic lead, copper, nickel, and cadmium. The workers associated with the brick plant, blast and converter furnaces, and Maerz furnace tear-down also were evaluated regarding their exposures to inorganic arsenic. Carbon monoxide exposures associated with the blast furnace charging and tending operations were evaluated. Environmental sampling in the electrorefining facility was limited to sulfuric acid and inorganic lead.

Exposures to the contaminants were evaluated using standard personal and/or work area sampling techniques. The sampling time was kept as close as possible to the entire 8- or 12-hour work shift. The airborne inorganic metals were collected on a 0.8 um pore-size polyvinylchloride copolymer membrane filter mounted in a 3-piece closed-face cassette in series with a vacuum pump operating a $1.5 \mathrm{lpm}$. The dust-laden filters were dissoived in concentrated phosphoric acid and the metal content determined using atomic absorption soectrophotometry. Arsenic could not be determined on the same filter as the other metals because of the requirements of the analytical procedure. Therefore, in filters were selected and analyzed for arsenic. The lower limits of analytical detection reported for lead, copper, zinc, nickel, cadmium and 
Page 5 - Health Hazard Evaluation Report HE 78-132

cadmium and arsenic were $4,3,4,3,2$, and 0.3 ug per filter, respectively. Sulfuric acid was collected on a 0.8 um pore-size mixed cellulose ester membrane filter mounted in a 3-piece closed face cassette using a vacuum pump operating at $1.5 \mathrm{lpm}$. The analyte was extracted from the filter with deionized water and analyzed with an ion chromatograph. The lower limit of analytical detection was 10 ug per filter. Carbon monoxide was measured using direct-reading gas detector tubes (Certification No. TC-84-102).

\section{B. Medical}

The medical evaluation included an interviewer-administered medical questionnaire, measurement of blood pressure, neurological examination, and collection of blood specimens. The questionnaire sought routine demographic information, occupational history, and symptoms associated with heavy metal poisoning. Blood pressure was measured with a standard adult aneroid sphygmomanometer. Diastolic pressure was recorded as the complete cessation of Korotkoff sounds or, if there was no cessation, as the point of muffling. The neurologic examination included testing of biceps, triceps, bronchioradialis, and Achilles tendon reflexes; finger, wrist, and plantor extensor strength; hand tremor; sensory-motor coordination. Blood specimens were analyzed for creatinine, calcium, phosphorous, glucose, urea nitrogen, total bilirubin, alkaline phosphatase, lactic dehydrogenase, glutamic oxacetic transaminase, glutamic pyruvic transaminase, white blood cell count, hematocrit, copper, lead, and erythrocyte protoporphyrin (EP). Analysis for EP was performed using the micro-scale photofluorometric method. (1)

\section{EYALUATION ERITERIA}

A. Environmental

The environmental evaluation criteria used for this study are presented in Appendix I. Listed for each substance are the recommended environmental limit, the source of the recommended limit, and the current OSHA standard.

\section{B. Medical}

A brief review of the known toxic effects of the hazardous substances to which Southwire workers are potentially exposed follows.

1. Inorganic Lead: Inhalation of lead dust and fumes is the major route of lead exposure in industry. A secondary source of exposure may be from ingestion of lead dust contamination on food, cigarettes, or other objects. Once absorbed lead is excreted from the body very slowly. The absorbed lead can damage the kidneys, peripheral and central nervous systems, and the blood forming organs (bone marrow). These effects may be felt as weakness, tiredness, irritability, digestive disturbances, high blood pressure, kidney damage, mental deficiency, or slowed reactrion times. Chronic lead exposure is associated with infertility and with fetal damage in pregnant women. 
Page 6 - Health Hazard Evaluatiọn Report HE 78-132

Blood lead levels below $40 \mathrm{ug} / 100 \mathrm{ml}$ whole blood are considered to be normal levels which may result from daily environmental exposure. However, fetal damage in pregnant women may occur at blood lead levels as low as $30 \mathrm{ug} / 100 \mathrm{ml}$. Lead levels between $40-60 \mathrm{ug} / 100 \mathrm{ml}$ in lead exposed workers indicate excessive absorption of lead and may result in some adverse health effects. Levels of 60 to $100 \mathrm{ug} / 10 \mathrm{ml}$ represent unacceptable elevations which may cause serious adverse health effects. Levels over $100 \mathrm{ug} / 100 \mathrm{ml}$ are considered dangerous and often require hospitalization and medical treatment.

The new OSHA standard for lead in air is $50 \mathrm{ug} / \mathrm{M}^{3}$ on an eight hour timeweighted average for daily exposure. For this particular industry the current standard is $50 \mathrm{ug} / \mathrm{M}^{3}$. Pending current litigation of the $50 \mathrm{ug} / \mathrm{M}^{3}$ lead standard, employers must achieve the $200 \mathrm{ug} / \mathrm{M}^{3}$ level (old OSHA standard) through engineering and administrative controls, and must protect workers at the $50 \mathrm{ug} / \mathrm{M}^{3}$ permissible exposure level through any combination of controls, including the use of proper respiratory protection. The standard also dictates that in four years workers with blood lead levels greater than $50 u g / 100 \mathrm{ml}$ must be immediately removed from further lead exposure and in some circumstances workers with lead levels less than $50 \mathrm{ug} / 100 \mathrm{ml}$ must also be removed. At present medical removal of workers is necessary at blood lead levels of $60 \mathrm{ug} / 100 \mathrm{ml}$ or greater. Removed workers have protection for wage, benefits, and seniority for up to eighteen months until their blood levels adequately decline and they can return to lead exposure areas.

2. Copper Fume and Dusts (2): Inhalation of copper fumes produces metal fume fever, which is characterized by chills, transient fever, nausea, thirst and exhaustion. Inhalation of dusts and mists of copper saits can result in congestion of the nose and throat, and on occasion, ulceration with perforation of the nasal septum.

3. Arsenic $(3,4)$ : Cancer is the most serious hazard of long-term exposure to arsenic. Arsenic can cause cancer of the skin, lungs, and liver. Spots (like warts) may appear on the skin of workers exposed to arsenic long before cancer develops (arsenical kerotosis). Arsenic can also cause irritation of the membranes of the eyes, nose, and throat, perforation of the nasal septum, nerve damage, and liver damage.

4. Inorganic Nickel(5): Metallic nickel can cause sensitization (allergic) dermatitis known as "nickel itch". Nickel dust may cause nasal or lung cancer in humans; and nickel fume in high concentrations is a respiratory irritant.

VI. RESULTS AND DISCUSSION

A. Environmental

1. Lead, Copper, Nickel, Cadmium and Zinc

A total of 47 personal samples were collected for airborne

inorganic lead. The analyses show that 10 values $\left(21.3 \%\right.$ ) exceed $200 \mathrm{ug} / \mathrm{m}^{3}$; 
Page 7 - Heaith Hazard Evaluation Report HE 78-132

18 values $(38.3 \%)$ were between 100 and $199 \mathrm{ug} / \mathrm{m}^{3} ; 10$ values (21.3\%) were between 50 and $99 \mathrm{ug} / \mathrm{m}^{3}$; and 9 values $(19.1 \%)$ were less than $50 \mathrm{ug} / \mathrm{m}^{3}$ (Table 1). By comparison, the OSHA standard is $50 \mathrm{ug} / \mathrm{m}^{3}$. The average afrborne lead concentrations by the seven job categories evaluated (Table 2 and Figure 1) are: cleaning of waste heat boilers - laborers $\left(2259 \mathrm{ug} / \mathrm{m}^{3}\right)$, baghouse attendant $\left(440 \mathrm{ug} / \mathrm{m}^{3}\right)$, gress brick operators $\left(161 \mathrm{ug} / \mathrm{m}^{3}\right)$, metals assistants and charges $\left(135 \mathrm{ug} / \mathrm{m}^{3}\right)$, Mearz tear down - laborers (117 $\left.\mathrm{ug} / \mathrm{m}^{3}\right)$, bedyard - auxiliary operators ( $\left.109 \mathrm{ug} / \mathrm{m}^{3}\right)$, and Sampling Dept. furnace personnel $\left(42 \mathrm{ug} / \mathrm{m}^{3}\right)$.

A tank house filtration operator was exposed to $813 \mathrm{ug} / \mathrm{m}^{3}$ of inorganic lead over a 40 minute period while shovelling slime from drying pans into barrels.

A total of 47 personal samples were collected for airborne copper (Tables 2 and 3). Figure 2 presents the average exposure concentrations by work areas. Thirteen were collected on personnel directly associated with the blast and converter furnaces or the Sampling Department furnace. Thus, these exposures were assumed to be copper fume. All of these 13 samples showed concentrations of copper fume (mean $390 \mathrm{ug} / \mathrm{m}^{3}$, range 120-988 $\mathrm{ug} / \mathrm{m}^{3}$ ) greater than the 100 $\mathrm{ug} / \mathrm{m}^{3}$ OSHA standard. Eight $(24 \%)$ of the 34 samples exceeded the 1000 $\mathrm{ug} / \mathrm{m}^{3}$ OSHA standard for copper dusts. Highest average copper dust concentrations were found in laborers cleaning the waste heat boilers (17584 $\left.\mathrm{ug} / \mathrm{m}^{3}\right)$, followed by mearz furnace tear-down personnel $\left(1243 \mathrm{ug} / \mathrm{m}^{3}\right)$ and bedyard auxiliary operators $\left(4158 \mathrm{ug} / \mathrm{m}^{3}\right)$.

Forty-seven personal samples were collected for airborne inorganic nickel (Table 4). Figure 3 presents the average exposure concentrations by work areas. Five (11\%) showed concentrations of nickel (mean $26 \mathrm{ug} / \mathrm{m}^{3}, \mathrm{range}$ $16-40 \mathrm{ug} / \mathrm{m}^{3}$ ) greater than the $15 \mathrm{ug} / \mathrm{m}^{3} \mathrm{NIOSH}$ recommended standard. These five samples included three of four collected from laborers cleaning the waste heat boiler, one of nine on bedyard auxiliary operators, and one of seven from press brick operators (Table 2).

Forty-seven personal samples were collected for airborne cadmium (Table 2). Figure 3 presents the average exposure levels by work areas. One (2.1\%) showed a concentration of cadmium $\left(45 \mathrm{ug} / \mathrm{m}^{3}\right)$ greater than the $40 \mathrm{ug} / \mathrm{m}^{3}$ NIOSH recommended standard (Table 5).

Forty-seven personal samples were collected for airborne zinc (Table 2). Figure 2 presents the average exposure levels by work areas. Thirteen of the 47 samples were collected on workers directly associated with furnace operations and are considered to be zinc oxide fume. None of the 13 samples showed a $z$ inc oxide fume concentration (average $490 \mathrm{ug} / \mathrm{m}^{3}$, range $260-1688$ $\mathrm{ug} / \mathrm{m}^{3}$ ) greater than the $5000 \mathrm{ug} / \mathrm{m}^{3}$ NIOSH recommended standard. Thirtyfour of the 47 samples were consjidered to be zinc dusts. The average zinc dust concentration was $1189 \mathrm{ug} / \mathrm{m}^{3}$ (range $125-36209 \mathrm{ug} / \mathrm{m}^{3}$ ).

Work area concentrations of airborne lead, copper, nickel, and cadmium were measured in the blast furnace control room on two consecutive days (Table 6 ). The sampler was positioned about 6 feet above the control room floor to 


\section{Page 8 - Health Hazard Evaluation Report HE 78-132}

approximate the breathing zone of the workers. On both days, the 8-hour timeweighted average lead concentration exceeded the $50 \mathrm{ug} / \mathrm{m}^{3}$ standard (mean 59 $\mathrm{ug} / \mathrm{m}^{3}$, range $\left.57-62 \mathrm{ug} / \mathrm{m}^{3}\right)$. The airborne concentrations of copper, zinc, nickel and cadmium were less than $29 \%$ of their respective criteria.

\section{Inorganic Arsenic}

A total of 10 personal samples were collected for airborne arsenic analysis (Table 7). The samples were collected on laborers involved in Maerz furnace tear-down, hot metals assistants, and press brick plant operators. Arsenic concentrations ranged from 0.72 to $3.2 \mathrm{ug} / \mathrm{m}^{3}$. Two (20\%) exceeded the $2 \mathrm{ug} / \mathrm{m}^{3} \mathrm{NIOSH}$ recommended standard.

\section{Carbon Monoxide}

Carbon monoxide concentrations were measured using direct reading colorimetric detector tubes in general work areas associated with the blast furnace (Table 8 ). The levels were all less than $29 \%$ of the $35 \mathrm{ppm}$ NIOSH recommended standard, except for two samples obtained 1-2 feet from the face of the blast furnace charging door during charging. These samples showed a carbon monoxide concentration of at least $700 \mathrm{ppm}$. By comparison, NIOSH recommends a ceiling value of $200 \mathrm{ppm}$. Although a worker could conceivably be in this high-exposure area, there was no indication that this occurs.

Considerable concern about carbon monoxide exposure existed among maintenance workers responsible for repairing the electronically controlled crane which operated about 40 feet above the blast and converter furnaces. Carbon monoxide concentrations measured on the crane, while positioned over the blast furnace, were less than $20 \mathrm{ppm}$ (Table 8 ).

Carbon monoxide levels measured in the Sampling Department around the quality control furnaces were less than $5 \mathrm{ppm}$.

\section{Sulfuric Acid}

Five samples were collected to evaluate tank house personnel exposures to airborne sulfuric acid (Table 9). The airborne sulfuric acid concentrations were less than $27 \%$ (mean $112 \mathrm{ug} / \mathrm{m}^{3}$, range $42-265 \mathrm{ug} / \mathrm{m}^{3}$ ) of the $1000 \mathrm{ug} / \mathrm{m}^{3}$ OSHA or NIOSH recommended standard.

\section{B. Medical}

\section{Study Population}

Two hundred ninety-three employees were evaluated. This number included 20 of approximately 100 contract maintenance workers on the Copper Division's list of 297 production employees. In addition, the employee sample included several auxilliary personnel also not listed. Hence we saw roughly $90 \%$ of production employees and roughly $73 \%$ of all persons who regularly work at the Copper Division of Southwire. 
Page 9 - Health Hazard Evaluation Report HE 78-132

The study population consisted of 282 men and 11 women: $75 \%$ were white, the remainder black. The mean age, of the white workers was 30.2 years, and that of the black workers 31.5, with ages ranging from 18 to 64 . Eighty-two percent of the population were aged 40 or less. For the purposes of epidemiologic analysis, employees were categorized as office workers, industrial supervisory personnel, or industrial workers. All employees were also divided into three groups on the basis of anticipated exposure to metallic dust and fume. The grouping of work areas is shown in Table 10.

\section{Symptoms}

Table lla shows the percent of employees in high, intermediate, and low exposure categories reporting a work-associated increase in symptoms in the year preceding the study. Employees in the high exposure group have a statistically significant increase of gastrointestinal symptoms, nonspecific fatigue and weakness, hand tremor, joint pain, and throat irritation. Since many of these symptoms could be associated with lead poisoning, we analyzed the prevalence of symptoms by erythrocyte protoporphyrin level (Table llb). Nausea, vomiting, and prevalence of hand tremor did not appear to be as closely associated with erythrocyte protoporphyrin level as they were with place of work within the Copper Division. Nor were they significantly associated with lead level. However, there was a strixing increase in abdominal pain: $44 \%$ of the workers with blood lead levels higher than $60 \mathrm{ug} / \mathrm{d}$ i had experienced abdominal discomfort within the preceding year as compared to $11 \%$ of those with lead levels of 60 or less (Table 11c). In addition, the prevalence of nocturia increases with increasing lead. Comparing workers with lead greater than or equal to 60 and erythrocyte protoporphyrin of 2000 or higher with those employees whose blood lead was 20 or less and erythrocyte protoporphyrin was 800 or less, led to no different associations of symptoms than had erythrocyte protoporphyrin groupings alone.

There was no significant relation of muscular cramps or nocturia to area of work, or to lead or erythrocyte protoporphyrin group. Nor were previous diagnoses of anemia, hypertension, gastritis, kidney or prostate disease associated with work area.

Table 12 shows respiratory symptoms among smokers and nonsmoking employees according to place of work, grouped according to anticipated metal and dust exposure. Fifty-four percent of workers in dusty areas were smokers compared to $60 \%$ in intermediate areas and $48 \%$ in low dust exposure areas. There were higher prevalences of respiratory symptoms among smokers, and chronic bronchitis, chronic phlegm production, and wheezing accompanied by shortness of breath were significantly increased in the dustiest work areas for smokers. In contrast, non-smokers who worked in dusty areas were more likely to experience morning cough in addition to chronic bronchitis and shortness of breath with wheezing. The prevalence of chest pain was similar in smokers and non-smokers in each work area, and when both smokers and non-smokers together were grouped according to exposure area, there was a significant increase in chest discomfort in dusty areas $(p=.0035$, not shown in Table 12). 
Page 10 - Health Hazard Evaluation Report HE 78-132

3. Physical Examination

\section{a. Blood Pressure}

The prevalence of hypertension (defined as systolic blood pressure $140 \mathrm{~mm} \mathrm{Hg}$ or greater or diastolic $90 \mathrm{~mm} \mathrm{Hg}$ or greater) was $38.7 \%$ among the male Copper Division employees. When compared to age, sex, and race-adjusted rates for the U.S. population $(16)$, this is a $30 \%$ increase, significant at the $p=.01$ level (Table 13). The rate of hypertension among black male employees was $51.4 \%$, a $50 \%$ increase over the expected age-adjusted rate. The most striking increase in hypertension prevalence was seen in the group of black employees ages 18-34; when black males in the age groups 18-24 and 25-34 are grouped together, the increase in prevalence of hypertension over national race and sex-specific figures is $78 \% p<.01,\left(x^{2}=6.67\right)$.

The definition of hypertension used above is a liberal one, and includes persons with borderline, definite, and severe hypertension. As shown in Table $13 \mathrm{a}$, the prevalence of borderline hypertension, defined as hypertension with a systolic less than 160 and a diastolic less than 95, was not significantly increased over the rates for the U.S. black and white age-adjusted male populations. In contrast, definite hypertension, defined as systolic blood pressure of 160 or greater $Q R$ diastolic of 95 or greater, was statistically increased $(p<.05)$ by $40 \%$ over U.S. rates (Table 13b). This increase is seen in both black (50\%) and white $(30 \%)$ workers. Again among black workers ages 18-34 the rate of definite hypertension is 2.6 times that of the comparable U.S. population of black males $\left(X^{2}=9.87, p<.01\right)$. Table $13 \mathrm{c}$ shows the rates of severe hypertension, defined as a diastolic blood pressure of at least 105 $\mathrm{mm} \mathrm{Hg}$. Although the number of such workers is too small to achieve statistical significance when compared to the national rates, the increased rate of white and black employees is similar to the increases seen for borderline and definite hypertension.

Another way of looking at blood pressure in this population is to examine mean systolic and diastolic pressures for the different age groupings, as shown in Table 13d. Overall, the mean diastolic blood pressure among Southwire male employees was increased $(p<.001)$ over the age and race-adjusted rate for Southern males, as were mean diastolics for both white and black populations. The increase in diastolic pressure was again most striking among the younger age groups of white and black employees. The mean systolic blood pressure in blacks was also significantly increased $(p<.01)$ in the $25-34$ age group.

There was no significant association between hypertension and lead level, either by regression or in grouped data. Nor were hypertensives distributed differently by erythrocyte protoporphyrin group. As would be predicted from these negative findings, dust and metal fume exposure groups also did not differ in mean systolic or diastolic blood pressure, nor in prevalence of hypertension. However, specific work areas varied considerably in the prevalence of hypertension. Definite hypertension rates between 30 and $40 \%$ occurred among maintenance workers distributed all over the plant, lift shop 
Page 11 - Health Hazard Evaluation Report HE 78-132

workers, and anode storage workers, as compared to $18 \%$ in the generai population. The prevalence of borderline hypertension was over $50 \%$ in the small number of baghouse and laboratory workers. Although the differences among hypertension prevalences were not of statistical significance, supervisors had a higher rate (49\%) of diastolic hypertension than did office workers (38\%) or industrial workers $(31 \%)$. As is usual in hypertension screening data, end-digit preference was not uniformly distributed: $44.5 \%$ of systolic blood pressures ended in zero, and $33.2 \%$ of diastolic. This compares to $46.9 \%$ and $43.9 \%$ for systolic and diastolic zerg digit preference in the national Health and Nutrition Examination Survey (13).

\section{b. Neurologic Examination}

Only two findings on neurologic examination were associated with elevated blood lead level: Achilles tendon (ankle) hyporeflexia and difficulty with rapid alternating movements (adiadochokinesia). The population with blood lead levels of $60 \mathrm{ug} \%$ or less had a $9.3 \%$ prevalence of decreased ankle reflexes as compared to a $25.9 \%$ of those with lead levels over $60(p=.0201)$. The prevalence of adiadochokinesia also increased as lead level increased, with $22.2 \%$ of the employees with lead levels over 60 showing such difficulty, as compared to $4.2 \%$ of the remaining workers $(p=.0009)$. This association was substantiated by an increased prevalence in the elevated erythrocyte protoporphyrin group. Although finger extensor weakness was seen primarily in the group with lead levels over 40 ug\% (5-fold increased rate), the number of employees having this finding are too small to achieve statistical significance. As shown in Table 14, there was no association between elevated blood lead level and abnormal finger to nose test, presence of hand tremor, other reflex abnormalities or muscle weakness. Only one patient had a positive Romberg sign or nystagmus, and only 3 were considered to have gait abnormalities.

There was no association between neurologic abnormalities and quantity of alcohol habitually consumed. Among the patients with abnormal rapid alternating movements, and excluding the three who averaged 3 or more drinks per day, only two persons had blood lead levels less than 40 ug\%, and one of these two had an elevated erythrocyte protoporphyrin. Their mean blood lead was 51 ug\% and mean EP $2267 \mathrm{ug} / 1$ erythrocytes. Only two of the 17 patients with adiadochokinesia had finger extensor weakness, and two others had decreased Achilles tendon reflexes.

\section{Laboratory Findings}

Table 10 shows the mean lead levels of workers in various areas of the plant grouped into high, intermediate, and low exposure groups. As would be predicted from the means of these categories of exposure to dust and fumes, the ranges varied markedly: six percent of the workers in the high exposure group had blood lead levels of $40 \mathrm{ug} \%$ or less, whereas only $5 \%$ of the low exposure population had lead levels above $40 \mathrm{ug} \%$, these being in laboratory workers. Two percent of intermediate exposure workers had lead levels over 60 ug\%, as compared to a majority in the high exposure group. The mean blood 
Page 12 - Health Hazard Evaluation Report HE 78-132

lead for the study population as a whole was 37.2 (standard deviation 16.5) with the highest being $83 \mathrm{ug} \%$. Only $17.6 \%$ were $20 \mathrm{ug} \%$ or 1 ower, and $38.7 \%$ were over $40 \mathrm{ug} \%$. Twenty-eight of 290 samples (9.7\%) were over $60 \mathrm{ug} \%$.

The mean erythrocyte protoporphyrin levels increased dramatically with increasing exposure category. The overall mean for the population was $1308 \mathrm{ug} / 1$ erythrocytes, and ranged as high as 10,548. The mean for a normal adult population is 518 with a standard deviation of 144 (17), comparable to the mean of the low exposure group. Table 15a shows the mean erythrocyte protoporphyrin for the various lead groupings. A linear regression analysis of log (erythrocyte protoporphyrin) versus blood lead yields a correlation coefficient of $r=0.731$.

Table 15b corroborates anecdotal accounts of dustier work conditions for evening and night shifts. Third shift workers had significantly elevated blood lead levels in all exposure groups, although the evening shift in the high exposure group had higher mean erythrocyte protoporphyrin levels than did the night shift. The 12-hour day workers in high and intermediate exposure groups had slightly higher mean blood lead levels than 8-hour day workers. For mean lead levels, shift and exposure group functioned independently; for erythrocyte protoporphyrin they were not independent although both were significantiy associated with statistically significant differences in mean EP level.

Supervisory personnel were not significantly protected from lead exposure as compared to industrial workers as a whole and in each exposure category (Table 15c). Office workers in the intermediate exposure group, which included the Maerz office and receiving area, had higher lead and erythrocyte protoporphyrin levels than other oftice workers.

Nonwhite workers had a mean lead value of 42.1 ug\% (S.U. $=1 / .2$ ) and white workers a mean of $35.3 \mathrm{ug} \%(\mathrm{S.U.}=\mid \mathrm{b} .8)$. The erythrocyte protoporphyrin mean was also elevated among the black workers. Whereas $1.3 \%$ of whites had lead values over $60 \mathrm{ug} \%$, the corresponding percentage in blacks was $16.0 \%$. Ihese racial ditterences in lead levels are best explained by lack underrepresentation among office workers and overrepresentation in high exposure industrial jobs.

tmployees who had worked over one year had higher lead and erythrocyte protoporphyrin levels than those with lesser tenure, in both high and intermediate exposure categories. The number of employees hired within the preceding year was too small to estimate the number of months before steady-state blood lead or erythrocyte protoporphyrin levels were reached. Ihere were tour employees with lead levels over $60 \mathrm{ug} \%$ who had worked tour months or less at the Copper Division; one of these, a blast turnace worker, had a lead level of 14 ug\% after 2 months employment.

Smokers had higher blood leads $(p=.04 b)$ and higher erythrocyte protoporphyrins $(p=.059)$ than non-smokers (Table 15d). However, in comparison with area of work, smoking accounted for a relatively small portion of the variance in blood levels. 
Page 13 - Health Hazard Evaluation Report HE 78-132

There were only five employees who may have had lead exposure apart from their occupation. Only two of these had lead levels greater than $40 \mathrm{ug} \%$ (each had part-time automobile repair work as the non-occupational exposure).

Seven employees had elevated serum copper levels (normal range $80-160$ ug\%), with the highest value being $239 \mathrm{ug} \%$ in an office worker with a blood lead of $11 \mathrm{ug} \%$. Only one of these seven had other abnormal metal values: a blast furnace worker with a serum zinc of $130 \mathrm{ug} \%$, lead of $59 \mathrm{ug} \%$ and erythrocyte protoporphyrin of $6359 \mathrm{ug} / 1$ erythrocytes. The remaining six had lead levels less than $40 \mathrm{ug}$, and half were lower than $15 \mathrm{ug} \%$. All seven worked the day shift, and three were office workers.

Nine employees had serum $z$ inc values above the normal range of $60-125$ ug\%, the highest being $339 \mathrm{ug} \%$ in an office worker. Only three had blood lead levels above $40 \mathrm{ug} \%$, and only one of these had a very high lead (76; with an erythrocyte protoporphyrin of 6055). Two of those with elevated zinc were office workers.

Anemia, defined as a hematocrit less than 40\%, was present in 12 employees, 3 of whom were women. The lowest hematocrit was 35, and this person had a blood lead of 26 and an erythrocyte protoporphyrin of 1862. Of the 12, only three persons had a lead level of greater than $40 \mathrm{ug} \%$, but all these levels were below $60 \mathrm{ug} \%$. Polycythemia, defined as a hematocrit greater than $50 \%$, was present in 12 employees, and 6 of them had leads of greater than $40 \mathrm{ug} \%$. There was no association of anemia or polycythemia with work area. Of interest, the highest lead found in the study, 83 ug\%, occurred in a bag house worker with a hematocrit of $50 \%$.

There were no persons with both abnormal creatinine (normal range to $1.5 \mathrm{ug} \%$ ) and BUN (range to 25), nor did mean creatinine increase significantly with increasing lead level (Table 15a). The high and intermediate exposure group together had a mean creatinine of $1.19 \mathrm{~g} \%$ as compared to a mean of $1.14 \mathrm{~g} \%$ for the low exposure group, a difference which is statistically significant at $p=.04$.

There were no significant differences among the 3 exposure. groups for the remaining blood tests. These included calcium, glucose, BUN, total bilirubin, alkaline phosphatase, lactic dehydrogenase, SGOT, SGPT, WBC, hematocrit, copper and zinc. The serum phosphorus was significantly higher in the high exposure group (3.62 vs 3.32 intermediate and 3.26 in low exposure groups); $p=.001)$.

VII. RECOMMENDATIONS

A. Exposure Control

1. Engineering 
a. The NIOSH investigation has determined that certain work activities involve excessive exposure to lead, copper, nickel and arsenic. Since the most significant and widespread overexposure is to lead, control priorities should be directed towards this substance with a target control value of less than $50 \mathrm{ug} / \mathrm{m}^{3}$.

b. While air lead control priorities should be directed primarily at those areas of highest exposure, consideration should be given to control of concentrations in work stations adjacent to these areas. For example, work area sampling conducted in the blast furnace control room showed that the average background levels $\left(59 \mathrm{ug} / \mathrm{m}^{3}\right)$ of lead exceeded the $50 \mathrm{ug} / \mathrm{m}^{3}$ OSHA standard. Since certain furnace affiliated personnel (such as foremen) spend a significant amount of $t$ ime in the control room, effort should be directed towards controlling the airborne lead level. This may require changes in both the control room's ventilation system and housekeeping procedures.

c. Engineering should be the principal means of controlling exposure to lead. A number of approaches may be used in combination, including isolation, enclosure, local exhaust ventilation, good plant design for ease and effectiveness of housekeeping, and procedures for materíals handling that avoid contamination of the workplace. Reference 14 identifies, evaluates, and characterizes the best available exposure controls presently being used in the secondary nonferrous smelting industry. The information offered in this publication may provide Southwire Company engineers with ideas for the successful control of employee exposure.

\section{Personal Protective Equipment}

\section{a. Respiratory Protection}

The use of respirators is not recommended as a primary means of exposure control. It should be employed in the following circumstances only

- during the time necessary to install engineering controls and institute work practices required to reduce excessive exposures;

- in work situations where engineering control methods and work practices are either technically not feasible or only feasible to an extent which is still insufficient to reduce the exposure to acceptable limits; or

- in emergencies or occasional brief non-routine exposures.

Respirators should be selected from those approved by NIOSH, and a respiratory program consistent with the requirements of the Occupational Safety and Health Act (29 CFR 1910.134 and 30 CFR 11) should be instituted. Close monitoring is required to maintain effectiveness of the program.

The specificity of respirators with respect to application and use should be thoroughly understood by the first-line supervisors and workers. Respirators designed for dusts will not prevent absorption of fumes. Where exposure is to lead fume, a fume respirator must be used. (NIOSH investigators observed workers exposed to lead fume wearing respirators designed for acid mists.) 
Page 15 - Health Hazard Evaluation Report HE 78-132

\section{b. Clothing}

Street clothes should not be used in lead-contaminated areas. Special work clothing should be worn. Street clothes and soiled work clothes must not be stored in the same locker. Separate lockers should be provided.

\section{Work Practices and Procedures:}

Adequate washing facilities should be provided and used by all workers. It is particularly important that workers wash carefully before eating and leaving for home.

Lunchroom facilities must be separate from the lead processing areas. Care should be taken that air and surfaces in the lunchroom are not contaminated with lead. Workers should wash before eating.

Dust suppression compounds or water should be used in dusty areas to minimize airborne metal-bearing dusts.

Dry sweeping should be avoided. The use of vacuum sweeping and water washing, where feasible, is preferred.

Smoking, eating, and drinking in lead-processing areas should-be prohibited. Smoking materials and foodstuffs should not be brought into the Tead-processing areas. Smoking is particularly hazardous. It affords an opportunity for direct ingestion of lead from the hands or the cigarette. Furthermore, particles of lead on cigarettes may be pyrolized and inhaled as a fume. 
Page 16 - Health Hazard Evaluation Report HE 78-132

\section{REFERENCES}

1. Chisolm, J.J. and D.H. Brown: Micro-scale Photof luorometric Determination of "Free Erythrocyte Porphyrin" (Proloporphyrin IX). Elinical Ehemistry $22: 1669-82(1975)$.

2. American Conference of Governmental Industrial Hygienists: Documentation of the Threshold Limit Values, Third Edition 1971, Third Printing 1976, Cincinnati, Ohio.

3. Occupational Safety and Health Standard, Subpart Z - Toxic and Hazardous Substances: Arsenic ...29 CFR 1910.1018.

4. NIOSH Criteria for a Recommended Standard ... Occupational Exposure to Inorganic Arsenic, Revised 1975.

5. NIOSH Criteria for a Recommended Standard ... Occupational Exposure to Inorganic Nickel, 1977.

6. NIOSH Criteria for a Recommended Standard ... Occupational Exposure to Inorganic Lead, Revised 1978.

7. Occupational Safety and Health Standards, Subpart Z - Toxic and Hazardous Substances: Lead ... 29 CFR 1910.1025.

8. Occupational Safety and Health Standard, Subpart Z - Toxic and Hazardous Substances ...29 CFR 1910.1000, 1978.

9. NIOSH Criteria for a Recommended Standard ... Occupational Exposure to Cadmium, 1976.

10. NIOSH Criteria for a Recommended Standard ... Occupational Exposure to Zinc Oxide, 1975.

11. NIOSH Criteria for a Recommended Standard ... Occupational Exposure to Sulfuric Acid, 1975.

12. NIOSH Criteria for a Recommended Standard ... Occupational Exposure to Carbon Monoxide, 1972.

13. National Center for Health Statistics: Blood pressure levels of persons 6-74 years, United States, 1971-1974 Hyattsville, Md: National Center for Health Statistics, 1977 (Vital and Health Statistics, Series 11: Data from the National Health Survey, No. 203) (DHEW publication no. (HRA) 78-1648 - Series 11. No. 203).

14. Burton, D.J., R.T. Coleman, W.M. Coltharp et al: Control Technology Assessment - The Secondary Nonferrous Smelting Industry. DHHS (NIOSH) Publication No. 80-143, 1980. 
Page 17 - Health Hazard Evaluation Report HE 78-132

\section{AUTHORSHIP AND ACKNOWLEDGEMENTS}

Report Prepared By:

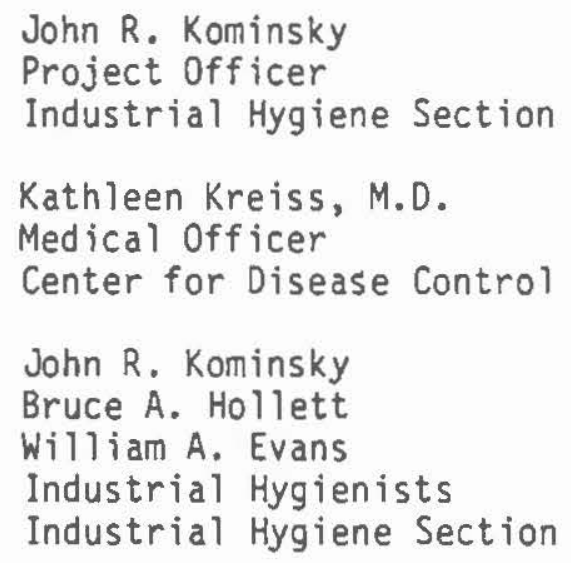

John R. Kominsky

Bruce A. Hollett

William A. Evans

Industrial Hygienists

Industrial Hygiene Section

Environmental Survey:

Medical Survey:

Kathleen Kreiss, M.D.

Mark Nelson, M.D.

Dorine Kramer, M.D.

Richard Wilson, M.D.

Stephen Crowley

Center for Disease Control

At lanta, Georgia

Thomas W. Mckinley

Pat Malone

Ralph C. Davis

Naresh K. Chawla

State of Georgia

Atlanta, Georgia

Originating Office:

Hazard Evaluations and Technical Assistance Branch

Division of Surveillance, Hazard

Evaluations and.Field Studies

Cincinnat $i$, Ohio

Report Typed By:

Odessa Brown

Clerk-Typist 
Page 18 - Health Hazard Evaluation Report HE 78-132

$X$. OISTR IBUTION ANO AVAILABILITY OF DETERMINATION REPORT

Copies of this Determination Report are currently available upon request from NIOSH, Division of Technical Services, Information Resources and Dissemination Section, 4676 Columbia Parkway, Cincinnati, Ohio 45226. After 90 days the report will be available through the National Technical Information Service (NTIS), Springfield, Virginia. Information regarding its availability through NTIS can be obtained from NIOSH, Publications Office at the Cincinnati address.

Copies of this report have been sent to:

a. Copper Division of Southwire, Southwire Company, Inc., Carrollton, Georgia 30117

b. Authorized representative of the employees at the Copper Division of Southwire, Southwire Company, Inc., Carrollton, Georgia

c. Regional Program Consultant, Region IV, NIOSH, Atlanta, Georgia 30323

d. Regional Administrator, Region IV, OSHA, U.S. Department of Labor, Atlanta, Georgia 30309

e. Director, Division of Physical Health, Georgia Department of Human Resources, State of Georgia, Atlanta, Georgia 30334.

For the purpose of informing the approximately 292 "affected employees" the employer shall promptly "post" for a period of 30 calendar days the Determination Report in a prominent place(s) near where exposed employees work. 


$$
\text { FIGURE } 1 .
$$

AVERAGE AIRBORNE LEAD EXPOSURES VS WORK AREA

$$
\begin{aligned}
& \text { SOUTHWIRE COMPANY, ING. } \\
& \text { CARROLLTON, GEORGIA } \\
& \text { OCTOBER } 2-6,1978
\end{aligned}
$$

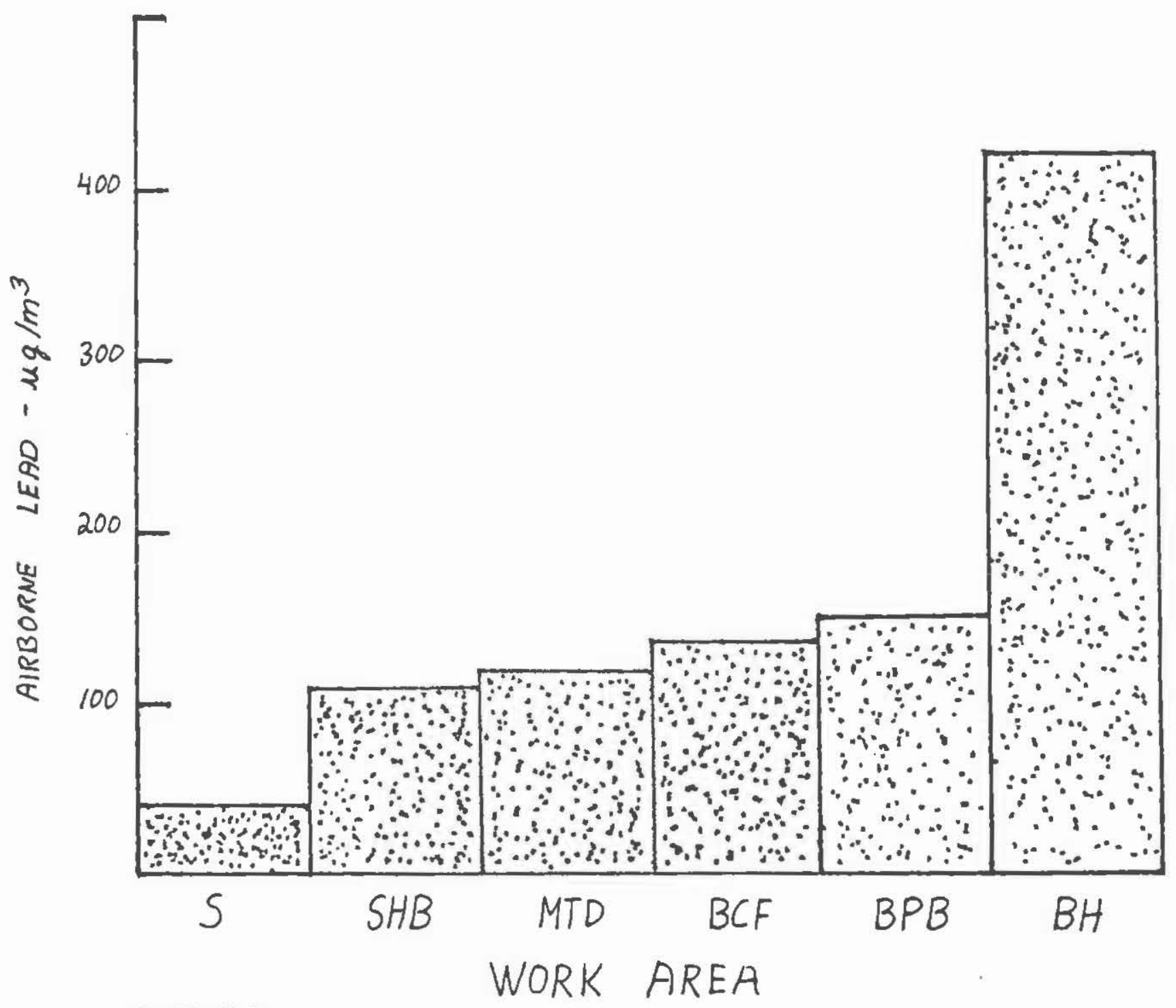

LEGEND:

$\begin{array}{llll}\text { S SAMPLING } & \text { BCF } & \text { BLAST-CONUERTER FUPNACE } \\ \text { SHB SCRAP HANOLING BEDVARD } & \text { BPB } & \text { BRICK PLANT BEDVARD } \\ \text { MTD MEARZ TEAR DOWN } & \text { BH } & \text { BAGHOUSE }\end{array}$




\section{FIGURE 2}

AVERAGE AIRBORNE COPPER AND 2 INC EXPOSURES US WORK AREA
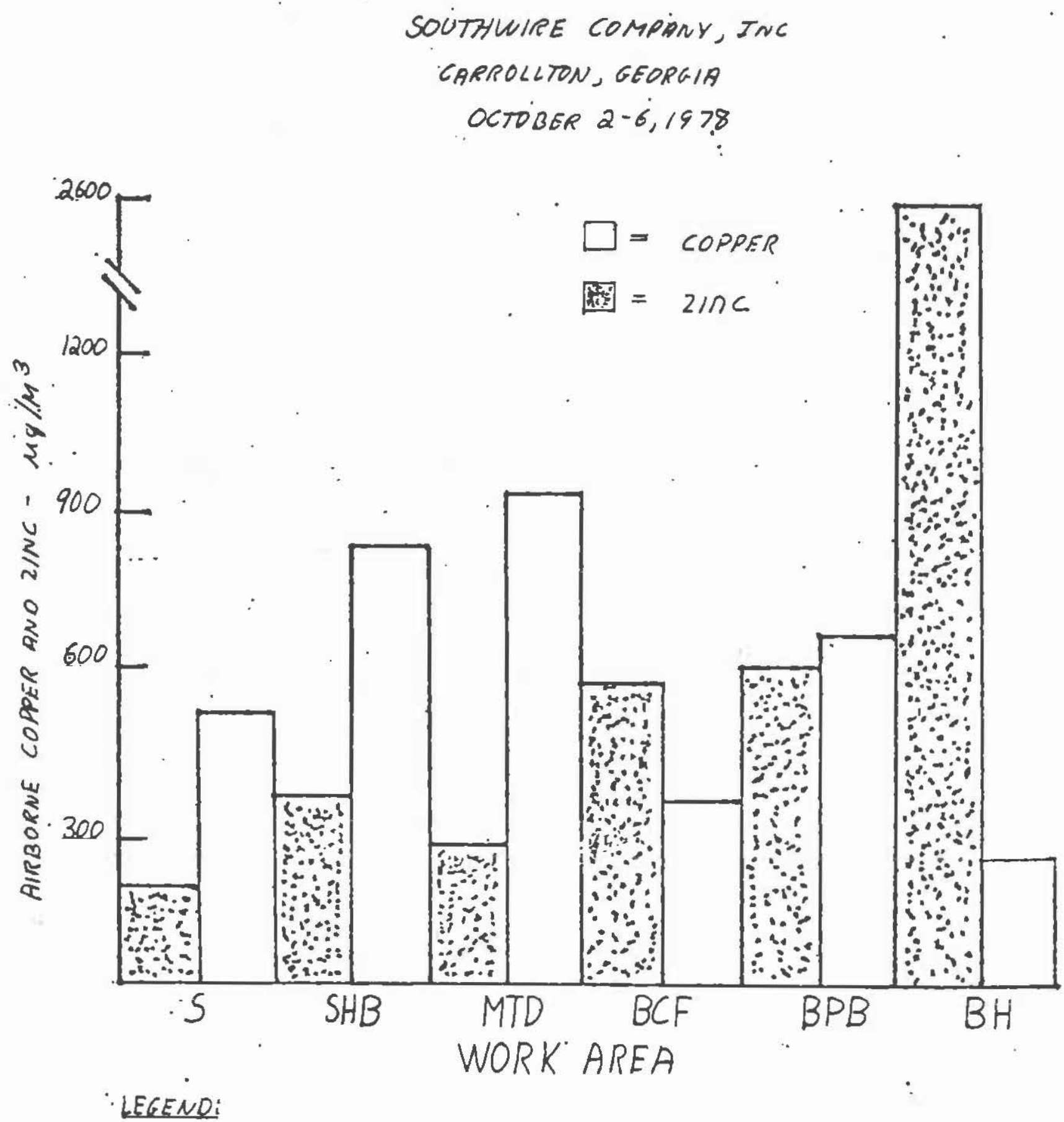

5 SAMPLING BCF BLAST.CQNUERTAR FURNACE

SHB SCRAP. HANOLING BEDVSTD BPB BRIGK PLANT BGOVARD:

MTD MEARZ TEAR DOWN BH BAGHOUSE 


\section{FIGURE 3}

AVERAGE AIRBORNE nickel and cadmiUm exposures VS WORK area

$$
\begin{aligned}
& \text { SOUTHWIRE COMPANY, INC } \\
& \text { CARROLLTON, GEORGIA } \\
& \text { OCTO3ER } 2-6,1978 .
\end{aligned}
$$

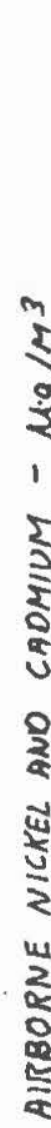

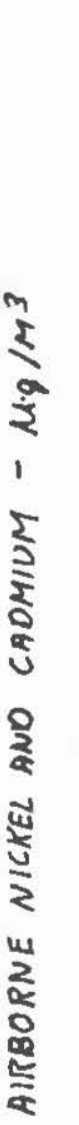

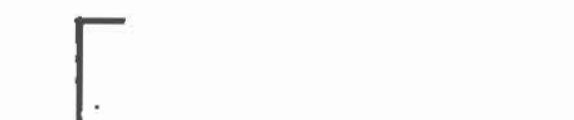

閣 = NICKEL

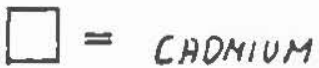

8.0

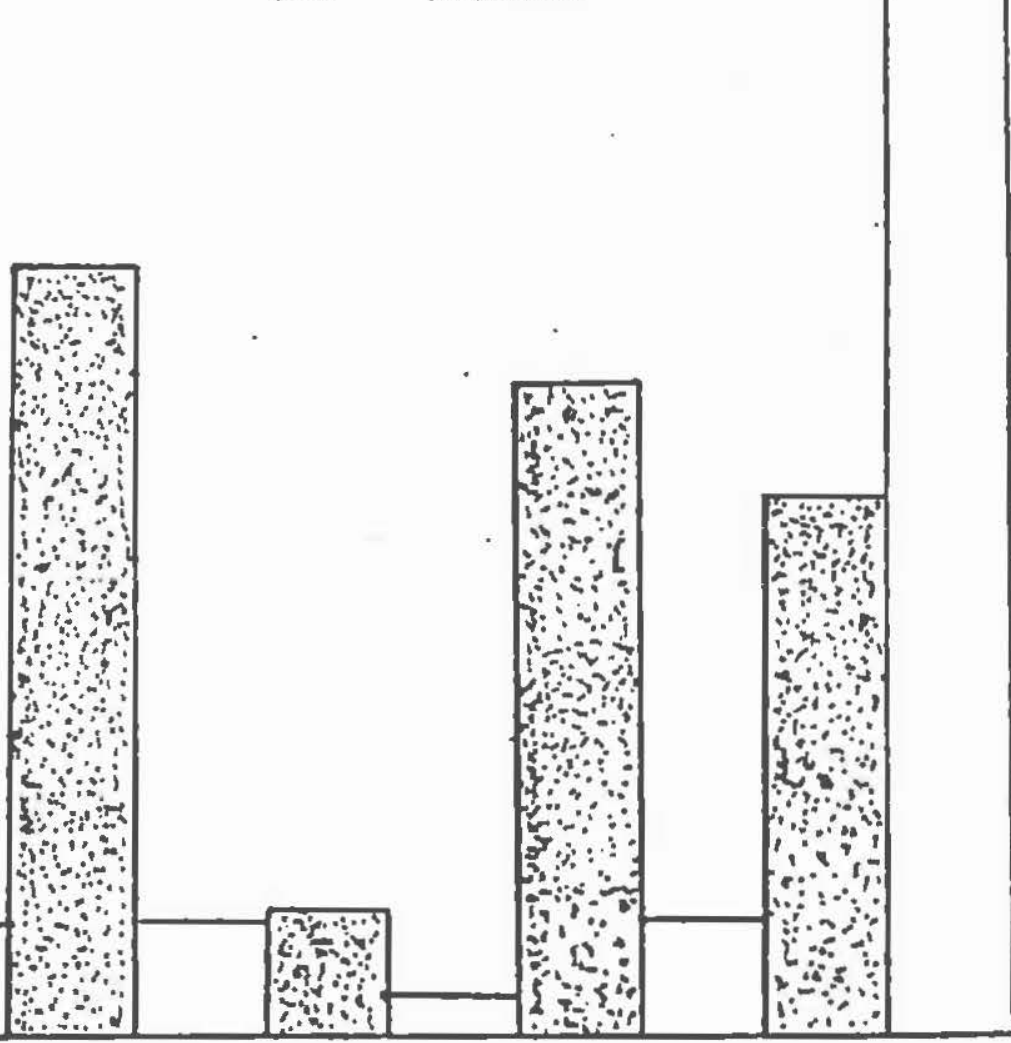

$S^{*} \cdot S H B$

MT D

$B C F$

$B P B$

$B H$

WORK AREA

LEGEND:

5 SAMPLING BCF BLAST-CONUERTER FURNACE

SHB SCRAP HANOLING BEDYARD BPB BRICK PLANT BEOYARD

MTD MEARZ TEAR DOWN BH BAGHOUSE

*ALL CAOMIUTS SAMOLES WERE $<2$ Mq. 
Table 1

Personal Exposures to Airborne Inorganic Lead

Southwire Company, Inc.

Carrollton, Georgia

October 2-6, 1978

\begin{tabular}{|c|c|c|c|c|c|c|c|c|c|}
\hline \multirow[b]{2}{*}{ Sample-Bescription } & \multirow{2}{*}{$\begin{array}{l}\text { No. of } \\
\text { Samples }\end{array}$} & \multirow{2}{*}{\multicolumn{2}{|c|}{$\begin{array}{l}\text { Distr } \\
\begin{array}{l}0-49 \\
\text { n-(\%) }\end{array}\end{array}$}} & \multirow{2}{*}{\multicolumn{2}{|c|}{$\begin{array}{l}\text { otion of Eo } \\
\begin{array}{l}50-99 \\
n \quad(\%)\end{array}\end{array}$}} & \multirow{2}{*}{\multicolumn{2}{|c|}{$\begin{array}{c}\text { Eoncentrations }= \\
\frac{100-199}{n}-(\%)\end{array}$}} & \multicolumn{2}{|c|}{$\frac{\mathrm{ag} / \mathrm{m}^{3}}{2004}$} \\
\hline & & & & & & & & $n$ & $(\%)$ \\
\hline Baghouse: attendant & 10 & & & 1 & $(10)$ & 6 & $(60)$ & 3 & $(30)$ \\
\hline $\begin{array}{l}\text { Blast/Converter Furnaces: Hot } \\
\text { Metals Assistants and Chargers }\end{array}$ & 10 & & & 2 & (20) & 7 & $(70)$ & 1 & $(10)$ \\
\hline $\begin{array}{l}\text { Maerz Furnace Tear Down: } \\
\text { Laborers }\end{array}$ & 4 & & & 3 & $(75)$ & & & 1 & $(25)$ \\
\hline $\begin{array}{l}\text { Maerz Furnace - Cleaning of } \\
\text { Waste Heat Boiler: Laborers }\end{array}$ & 4 & & & & & & & 4 & $(100)$ \\
\hline $\begin{array}{l}\text { Sampling Dept: Furnace Operator, } \\
\text { Tender and Weigher }\end{array}$ & 3 & 3 & $(100)$ & & & & & & \\
\hline $\begin{array}{l}\text { Bedyard (Scrap Handling) } \\
\text { Auxiliary Operators }\end{array}$ & 9 & 4 & (44) & 2 & (22) & 3 & (33) & & \\
\hline $\begin{array}{l}\text { Bedyard (Brick Plant): } \\
\text { Press Brick Operators }\end{array}$ & 7 & 2 & $(29)$ & $\underline{z}$ & $(29)$ & $\underline{z}$ & $(29)$ & 1 & $(14)$ \\
\hline Total & 47 & 9 & $(19.1)$ & 10 & $(21.3)$ & 18 & $(38.3)$ & 10 & $(21.3)$ \\
\hline
\end{tabular}




\section{Table 2}

Summary of Lead, Copper, Nickel, Cadmlum and Zinc Personal Sampling Results

(Personal Exposures - ug/m 3 )

Southwire Company, Incorporated

Carrollton, Georgia

October 2-6, 1978

\begin{tabular}{|c|c|c|c|c|c|c|c|c|c|c|c|}
\hline \multirow[b]{2}{*}{ Sample Description } & \multirow{2}{*}{$\begin{array}{l}\text { No. of } \\
\text { Samples }\end{array}$} & \multicolumn{2}{|c|}{ tead } & \multicolumn{2}{|c|}{ Eopper } & \multicolumn{2}{|c|}{ Nickel } & \multicolumn{2}{|c|}{ Eadmium } & \multicolumn{2}{|c|}{ Tine } \\
\hline & & Mean & Range & Mean & Range & Mean & Range & Mean & Range & Mean & Range \\
\hline Baghouse Attendant & 10 & 440 & $82-2012$ & 256 & $80-790$ & 2.3 & LLD*-9.0 & 9.5 & LLD-45 & 2584 & $298-8446$ \\
\hline $\begin{array}{l}\text { Blast/Converter Furnaces: } \\
\text { Metals Assts. \& Charger }\end{array}$ & 10 & 135 & $70-212$ & 348 & $120-988$ & 0.98 & LLD-5.5 & 0.28 & LLD-2.8 & 574 & $153-1688$ \\
\hline $\begin{array}{l}\text { Mearz Tear Down: } \\
\text { Laborers }\end{array}$ & 4 & 117 & $77-221$ & 1243 & $438-2702$ & 6.3 & $4.1-8.7$ & 0.83 & LLD -3.3 & 250 & $192-435$ \\
\hline $\begin{array}{l}\text { Cleaning of Waste Heat Boiler: } \\
\text { Laborers }\end{array}$ & 4 & 2259 & $536-4812$ & 17584 & $5358-36209$ & 26 & $9.7-40$ & 23 & $6.4-37$ & 3768 & $781-6702$ \\
\hline $\begin{array}{l}\text { Sampling Dept.: Furnace Opr., } \\
\text { Tender and Weigher }\end{array}$ & 3 & 42 & $34-47$ & 532 & $260-846$ & 1.4 & LLD-4.3 & - & - & 210 & $190-224$ \\
\hline $\begin{array}{l}\text { Bedyard (Scrap Handling): } \\
\text { Auxiliary Operators }\end{array}$ & 9 & 109 & $33-360$ & 848 & $191-4158$ & 5.2 & LLO-16 & 0.83 & LLD -6.5 & 351 & $117-1190$ \\
\hline $\begin{array}{l}\text { Bedyard (Brick Plant): } \\
\text { Press Brick Operator } \\
\quad \ldots \ldots \ldots\end{array}$ & 7 & 151 & $\begin{array}{c}35-612 \\
\ldots\end{array}$ & $\begin{array}{r}654 \\
\cdots\end{array}$ & $155-2330$ & 4.8 & LLD-17 & $\begin{array}{l}2.5 \\
\ldots .\end{array}$ & $\begin{array}{l}\text { LLO-12 } \\
\quad \ldots\end{array}$ & $\begin{array}{r}601 \\
\ldots \quad \ldots\end{array}$ & $128-2427$ \\
\hline
\end{tabular}


Table 3

Personal Exposures to Airborne Copper

Southwire Company, Incorporated

Carrollton, Georgia

October 2-6, 1978

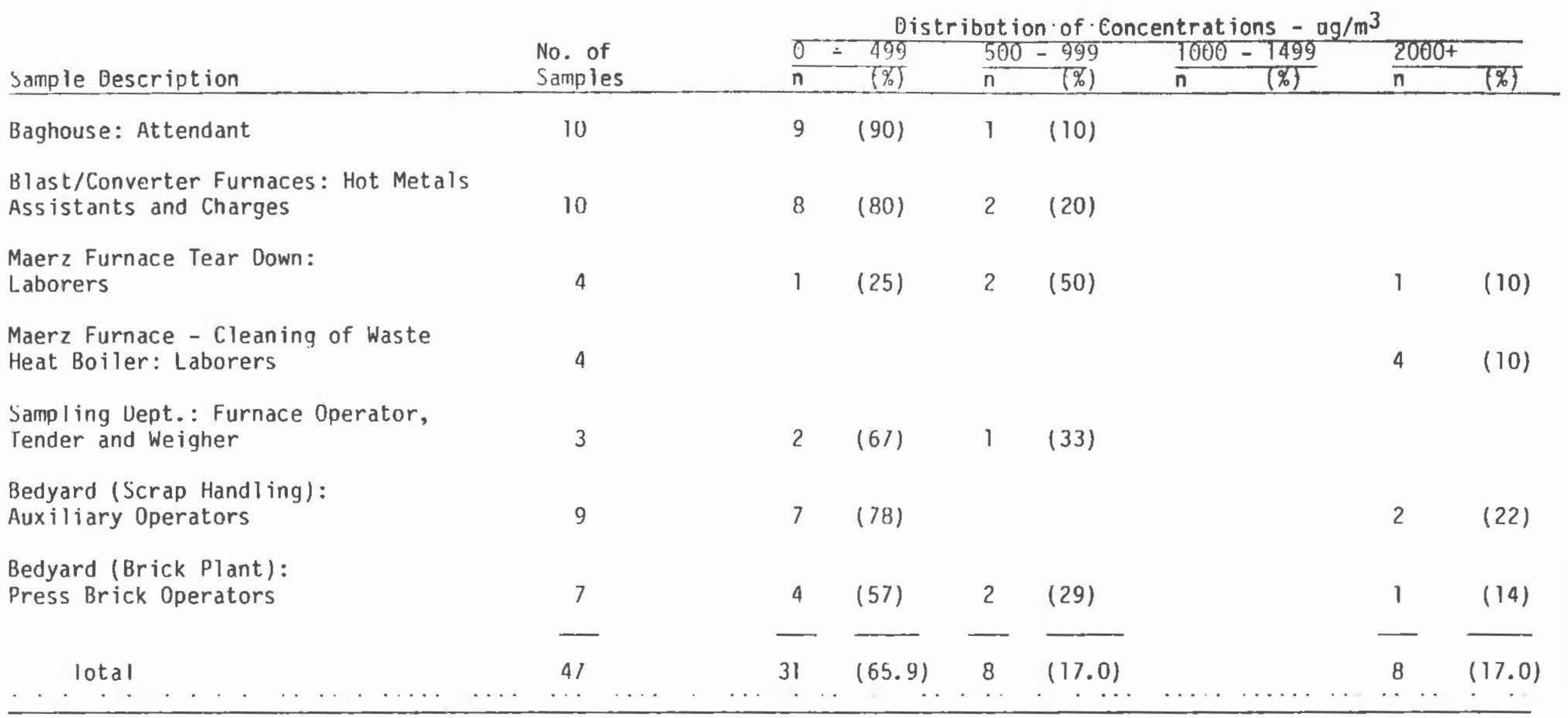


Table 4

Personal Exposures to Airborne Inorganic Nickel

Southwire Company, Incorporated

Carroliton, Georgia

October 2-6, 1978

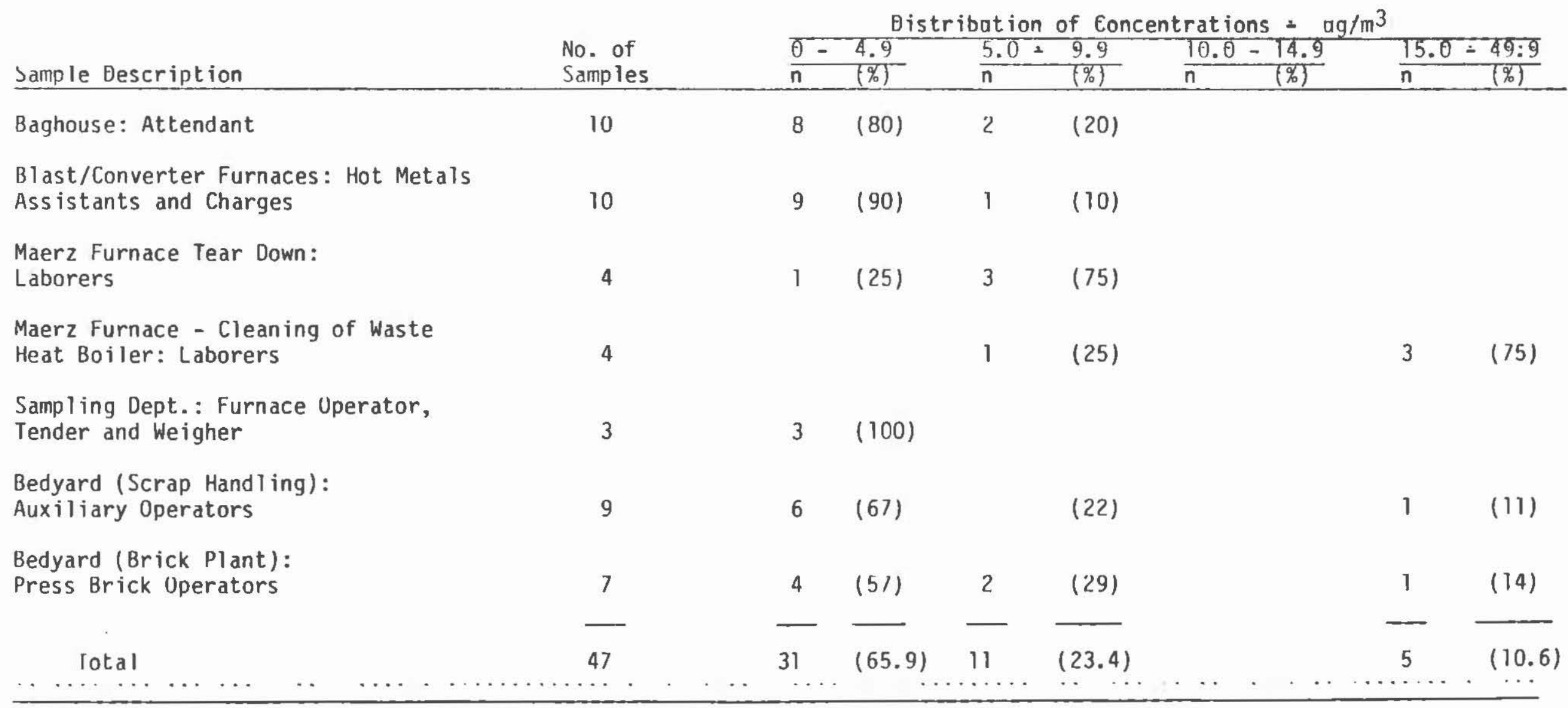


Table 5

Personal Exposures to Airborne Cadmium

Southwire Company, Incorporated

Carrollton, Georgia

October 2-6, 1978

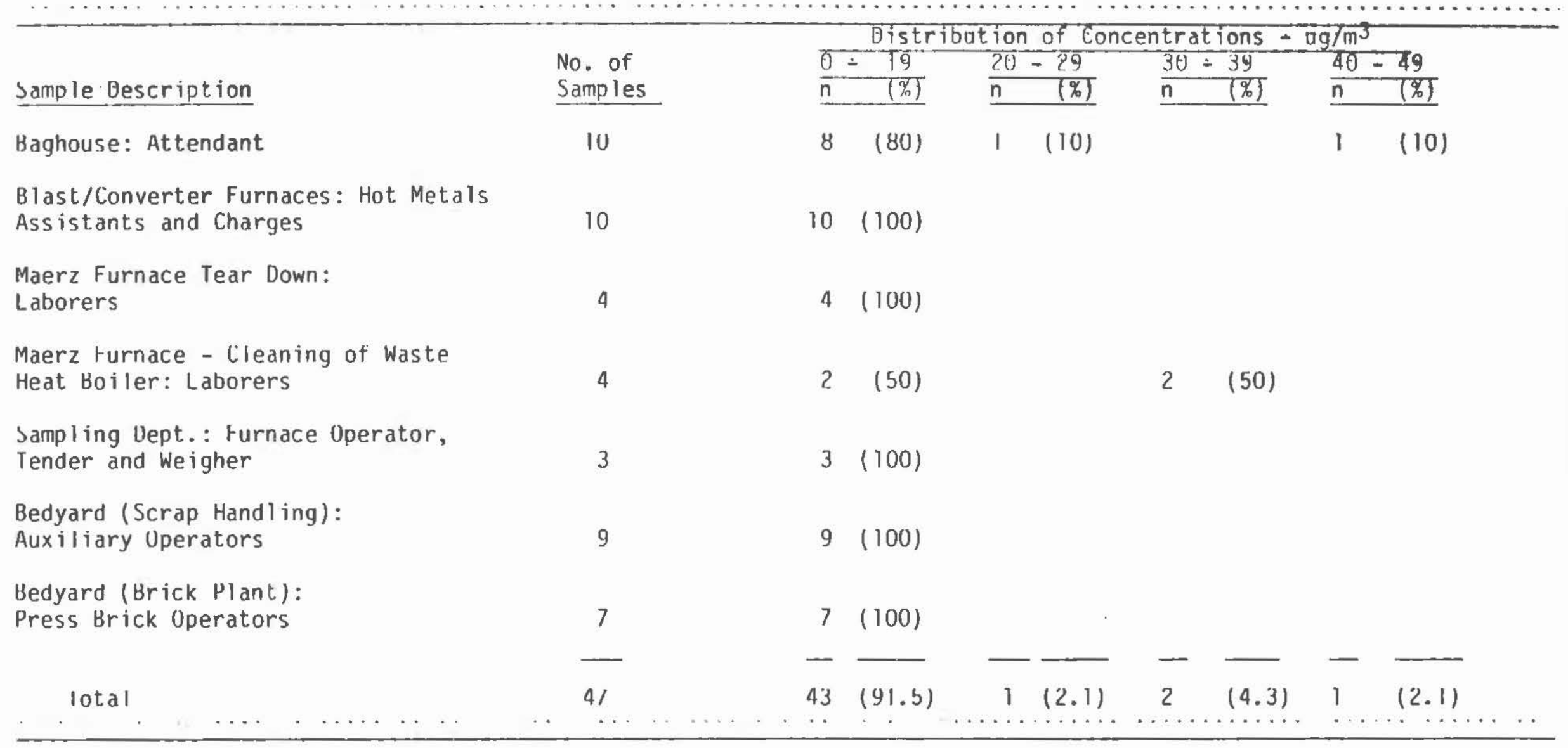




$$
\text { Table } 6
$$

Blast Furnace Control Room -

Work Area Levels of Metallic Aerosols

Southwire Company, Incorporated

Carrollton, Georgia

October $4-5,1978$

\begin{tabular}{|c|c|c|c|c|c|c|c|}
\hline \multirow[b]{2}{*}{ Bate } & \multirow[b]{2}{*}{ Sample tocation } & Sample & \multicolumn{5}{|c|}{ Airborne Concentration - ug/M3 } \\
\hline & & Time-Hrs & Eead & Copper & Zine & Nicke & Eadmium \\
\hline $10-4$ & $6 \mathrm{ft}$ above floor & 7.55 & 57 & 44 & 221 & 4.4 & LLD \\
\hline $10-5$ & $6 \mathrm{ft}$ above floor & 7.67 & 62 & 60 & 185 & $\angle L D^{A}$ & LLD \\
\hline$\ldots$. & $\ldots$ & . . & $\ldots$ & . $\quad \ldots$ & $\ldots$ & . & . . \\
\hline
\end{tabular}

ALower Limit of Detection. The LLO's for nickel and cadmium are 3 and 2 ug per sample, respectively. 


\section{Table 7}

\section{Personal Exposures to Arsenic \\ Southwire Company, Incorporated \\ Carrollton, Georgia}

October 3-5, 1978

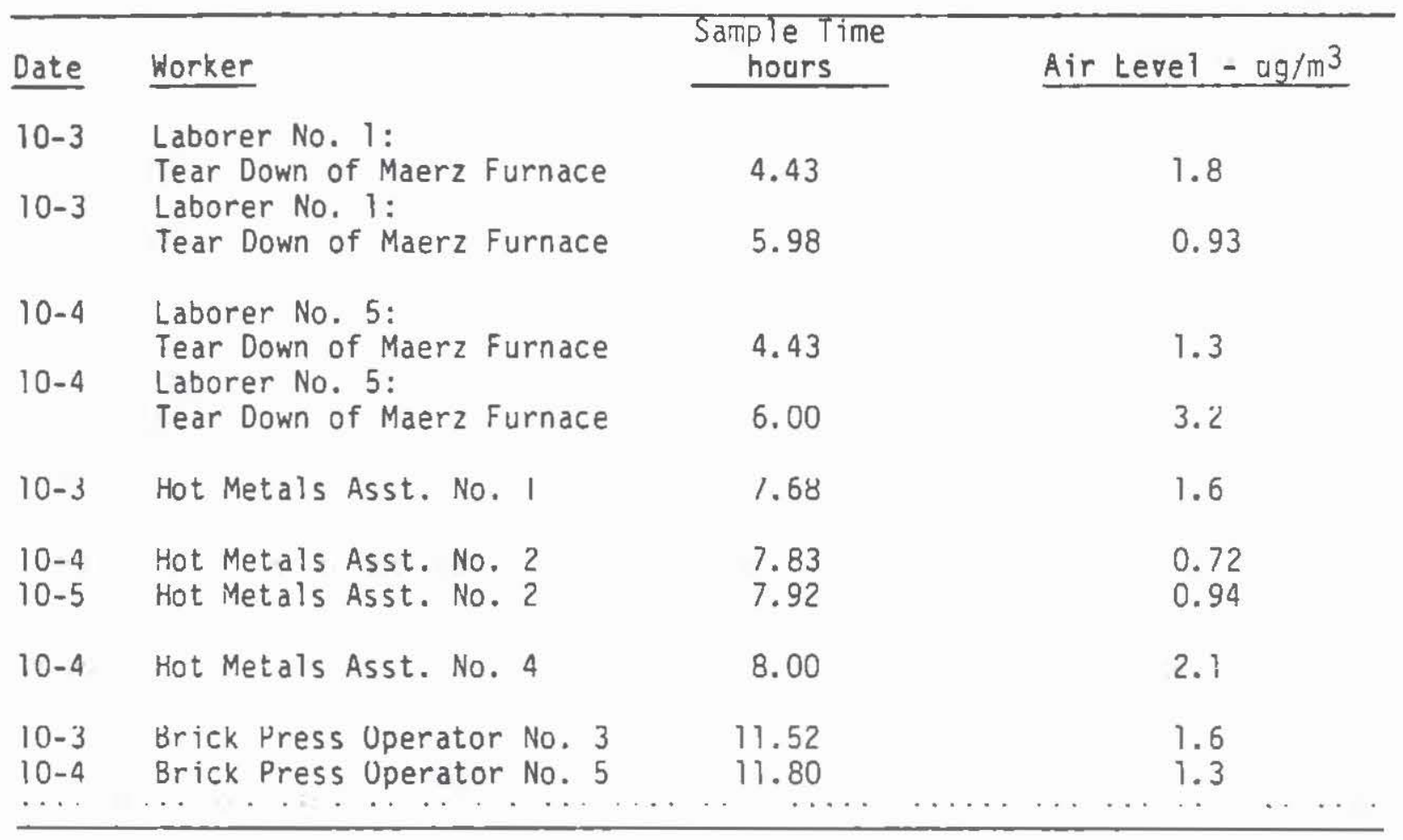


Table 8

Exposures to Carbon Monoxide

Southwire Company, Incorporated

Carrollton, Georgia

October 4, 1978

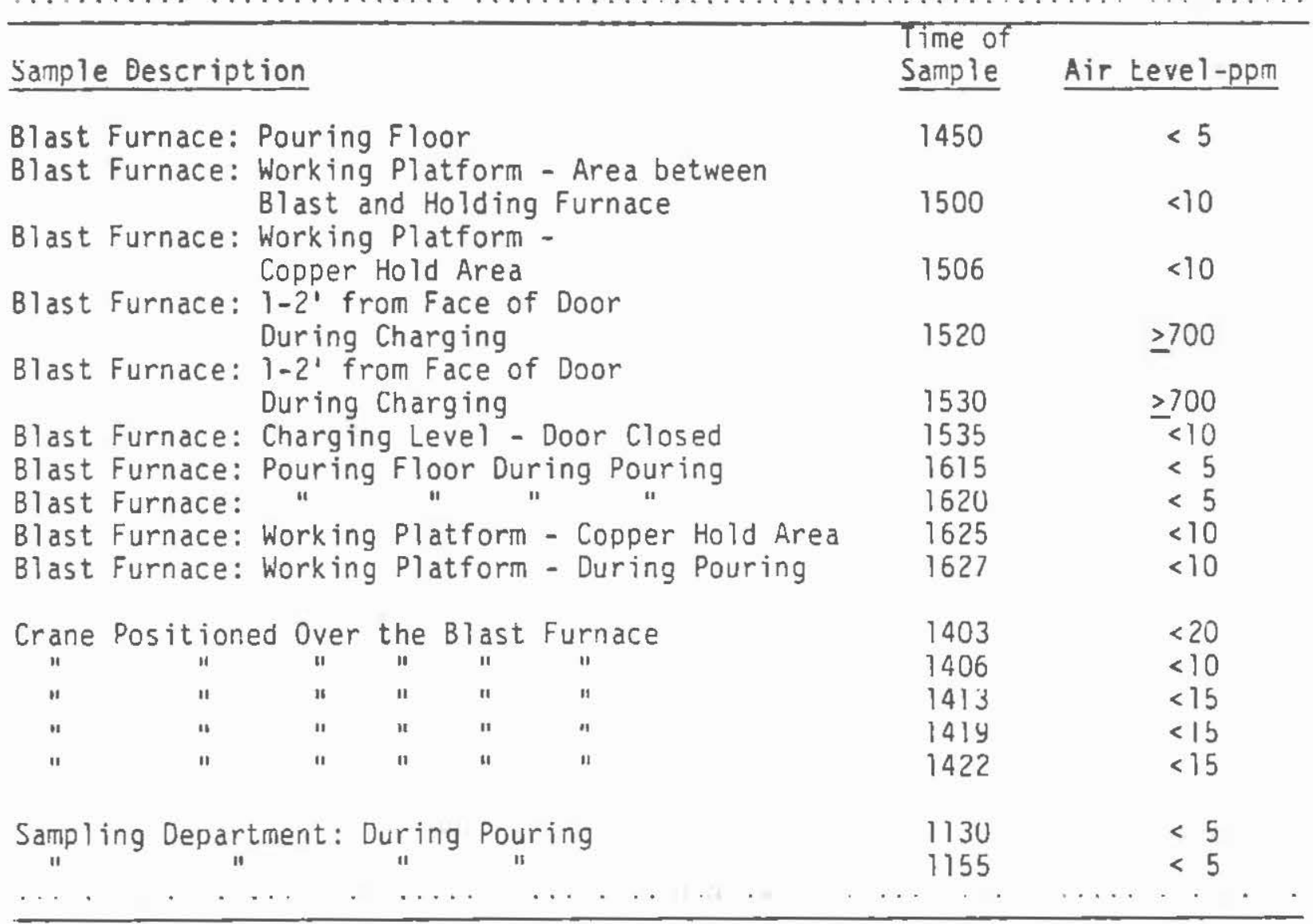


Table 9

Tank House - Sulfuric Acid Exposures

Southwire Company, Incorporated Carrollton, Georgia

October 5, 1978

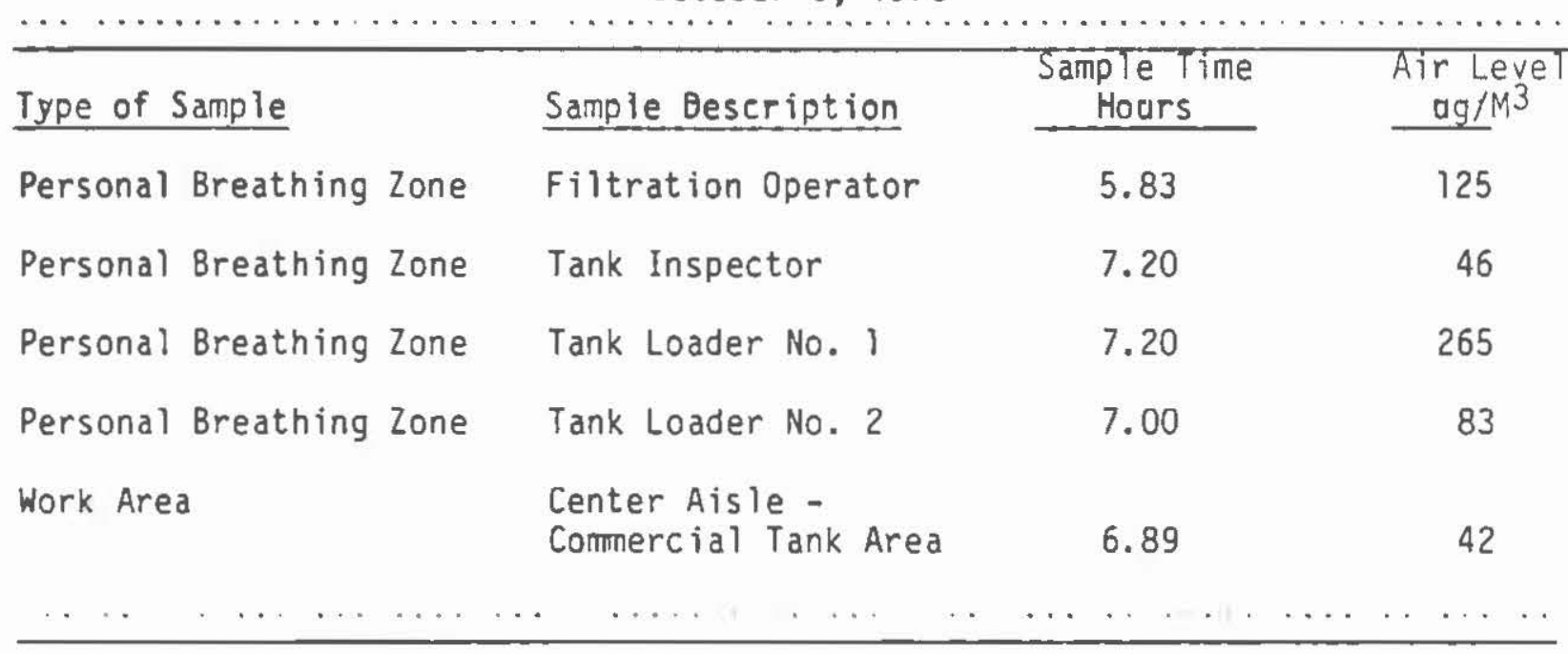


Table 10

Mean Blood Lead and Erythrocyte Protoporphyrin

in Workers by Work Area

Southwire Company, Incorporated

Carroliton, Georgia

October 4-11, 1978

\begin{tabular}{|c|c|c|c|}
\hline & $\begin{array}{l}\text { No. of } \\
\text { Employees }\end{array}$ & $\begin{array}{l}\text { Mean } \\
\text { Lead } \\
\text { ug\% }\end{array}$ & $\begin{array}{l}\text { Mean erythrocyte } \\
\text { protoporphyrin } \\
\text { ag/1 of erythrocytes }\end{array}$ \\
\hline $\begin{array}{l}\text { High Exposure } \\
\text { Baghouse } \\
\text { Boiler } \\
\text { 8last Furnace }\end{array}$ & $\begin{array}{r}48 \\
7 \\
3 \\
38\end{array}$ & $\begin{array}{l}61.8 \pm 12.1 \\
58.1 \pm 16.8 \\
54.7 \pm 15.0 \\
63.0 \pm 11.0\end{array}$ & $\begin{array}{l}3736 \pm 2330 \\
2664 \pm 1825 \\
1450 \pm 1290 \\
4114 \pm 2354\end{array}$ \\
\hline $\begin{array}{l}\text { Intermediate Exposure } \\
\text { Entire plant } \\
\text { Bed Yard } \\
\text { Brick House } \\
\text { Maerz Furnace } \\
\text { Casting Operation } \\
\text { Sampling Furnace } \\
\text { Receiving Area } \\
\text { Anode Storage Area }\end{array}$ & $\begin{array}{r}141 \\
37 \\
19 \\
3 \\
35 \\
5 \\
12 \\
20 \\
10\end{array}$ & $\begin{array}{l}38.4 \pm 11.0 \\
35.5 \mp 10.1 \\
43.8 \div 8.2 \\
44.7 \mp 4.0 \\
37.9 \pm 12.4 \\
33.4 \mp \frac{7}{\mp} 3.4 \\
40.2 \mp 9.4 \\
41.7 \mp 11.9 \\
33.1 \pm 12.5\end{array}$ & $\begin{array}{r}1024 \pm 683 \\
843 \mp 380 \\
941 \pm 665 \\
984 \mp 697 \\
1181 \pm 865 \\
1531 \pm 1187 \\
824 \pm 344 \\
1173 \mp 754 \\
1008 \pm 633\end{array}$ \\
\hline $\begin{array}{l}\text { Low-Exposure } \\
\text { Tank House } \\
\text { Nickel Sulfate Plant } \\
\text { Lift Shop } \\
\text { Laboratories } \\
\text { Offices }\end{array}$ & $\begin{array}{r}100 \\
55 \\
3 \\
8 \\
3 \\
31\end{array}$ & 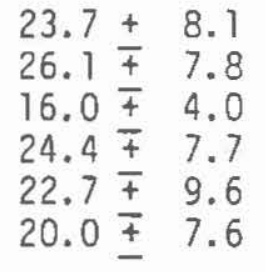 & $\begin{array}{l}547 \pm 208 \\
541 \div 202 \\
517 \mp 184 \\
682 \div 358 \\
588 \mp 211 \\
521 \pm 169\end{array}$ \\
\hline Total Population & 289 & $37.2 \pm 16.4$ & $1308 \pm 1531$ \\
\hline$\ldots \ldots, \quad \cdots \quad \cdots \quad \cdots$ & & 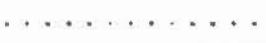 & $\ldots, \ldots, \cdots, \ldots$ \\
\hline
\end{tabular}


Table lla

Work Associated Symptoms in the Preceding Year

Among Southwire Employees by Place, 1978

Southwire Company, Incorporated

Carrollton, Georgia

October $4-11,1978$

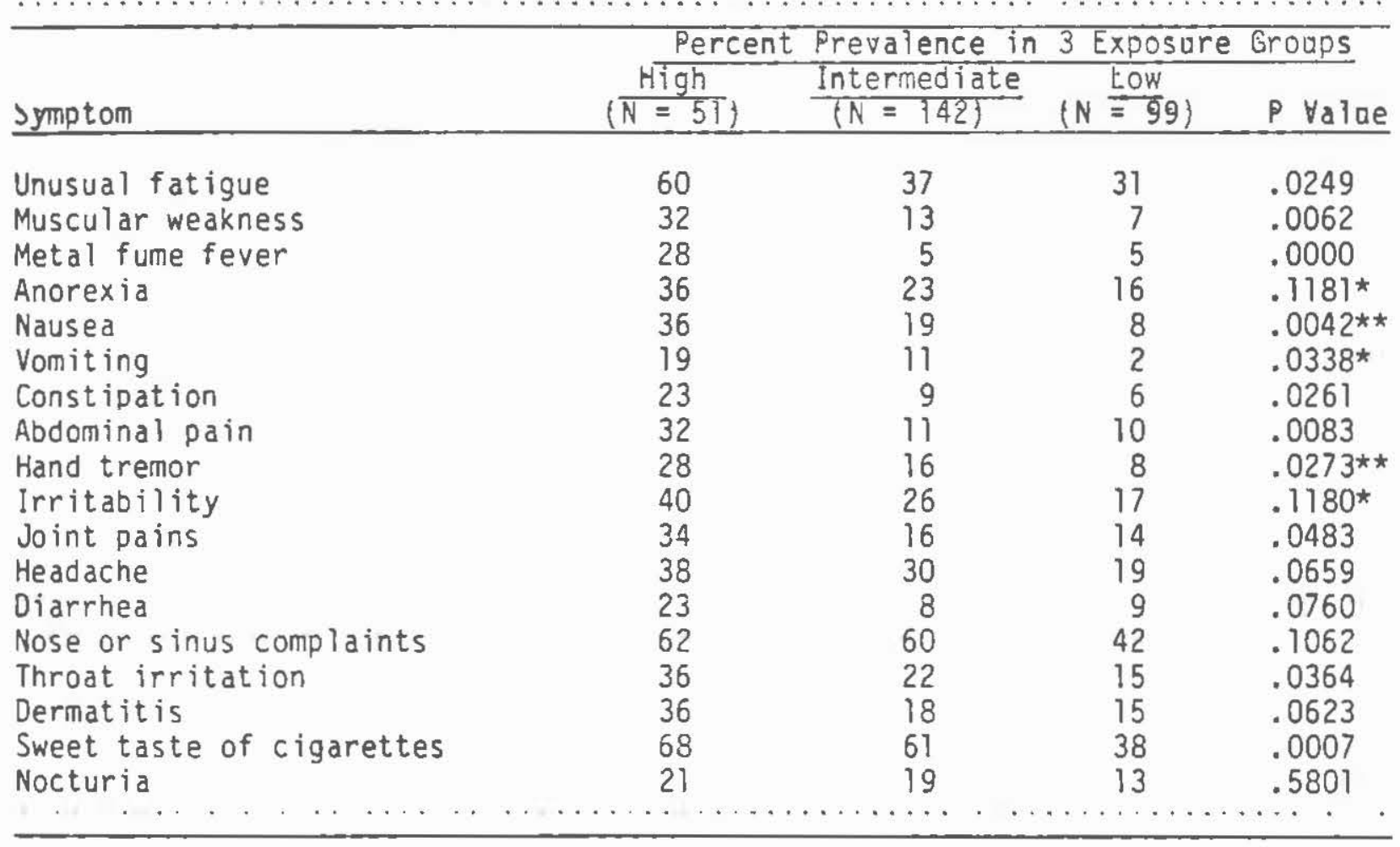

* Significant at $p<.01$ when analyzed by employees grouped by erythrocyte protoporphyrin into those $E P \leq 800,801-2000,2000 \mathrm{ug} / 1$

\# Not significant by employees grouped by erythrocyte protoporphyrin levels 
Table 11b

Work-Associated Symptoms in the Preceding Year Among

Southwire Employees Grouped by Erythrocyte Protoporphyrin Level

Southwire Company, Incorporated

Carrollton, Georgia

October 4-19, 1978

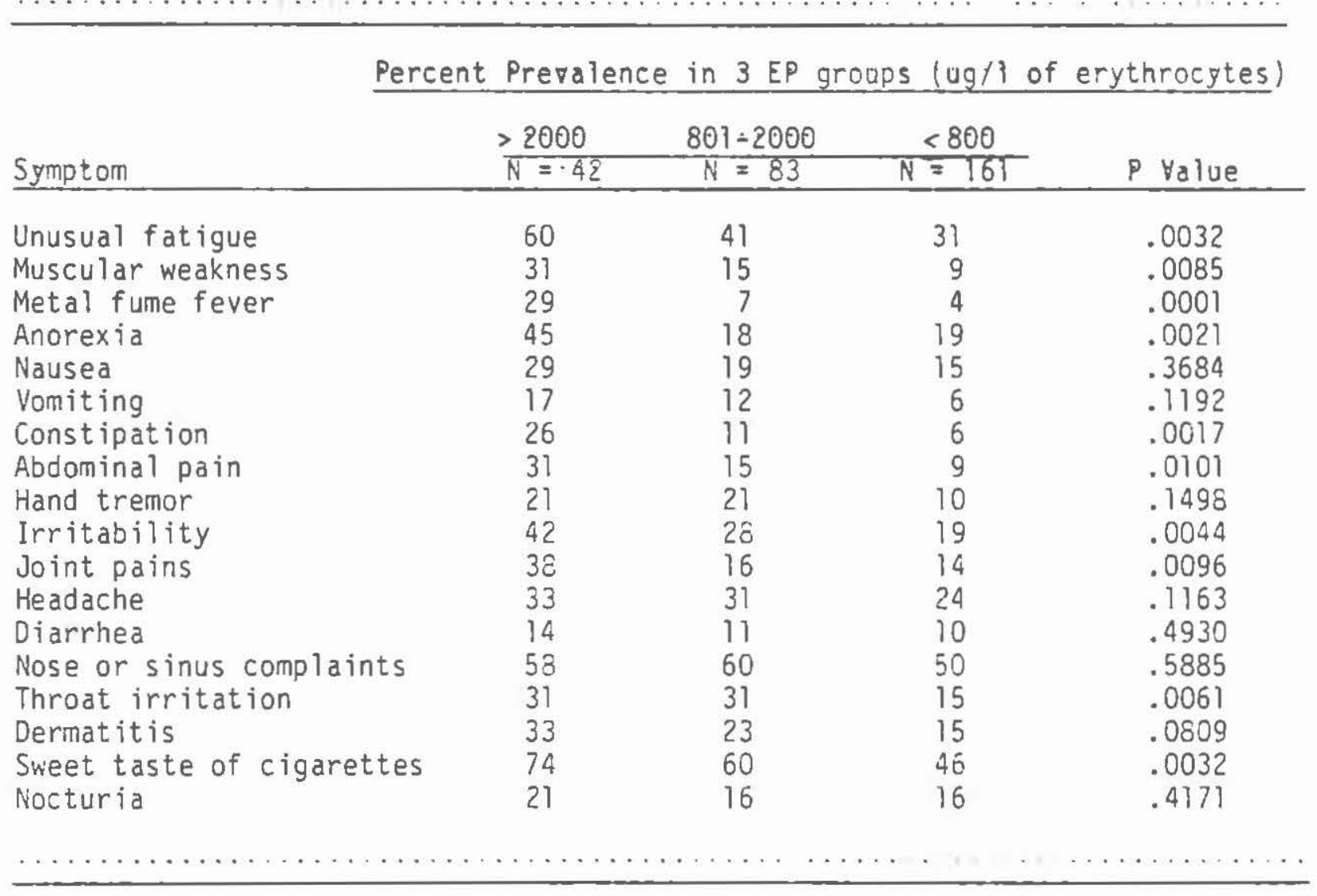


Table 11c

Work Associated Symptoms in the Preceding Year

Among Southwire Employees Grouped by Lead Level

Southwire Company, Incorporated

Carroliton, Georgia

October $4-11,1978$

\begin{tabular}{|c|c|c|c|c|c|}
\hline Symptoms & $<\frac{P \text { Perc }}{20}$ & $\begin{array}{l}t \text { Preva } \\
21-40 \\
N=126\end{array}$ & $\begin{array}{l}\frac{c e \text { acco }}{4 !-60} \\
N=84\end{array}$ & $\frac{\frac{\text { ng to }}{360}}{N=27}$ & $\begin{array}{r}\text { lead: }(0 \mathrm{~g} \%) \\
\text { P Value }\end{array}$ \\
\hline Unusual fatigue & 18 & 38 & 41 & 67 & .0008 \\
\hline Muscular weakness & 4 & 11 & 18 & 33 & .0165 \\
\hline Metal fume fever & 6 & 4 & 12 & 26 & .0074 \\
\hline Anorexia & 10 & 21 & 26 & 37 & .0728 \\
\hline Nausea & 10 & 16 & 20 & 37 & .0884 \\
\hline Vomiting & 2 & 9 & 14 & 11 & .2844 \\
\hline Constipation & 4 & 8 & 11 & 30 & .0054 \\
\hline Abdominal pain & 8 & 10 & 14 & 44 & .0001 \\
\hline Hand tremor & 10 & 10 & 19 & 33 & .0307 \\
\hline Irritability & 6 & 28 & 25 & 48 & .0069 \\
\hline Joint pains & 6 & 15 & 23 & 41 & .0103 \\
\hline Headache & 14 & 27 & 32 & 33 & .0728 \\
\hline Diarrhea & 10 & 9 & 11 & 22 & .3449 \\
\hline Nose or sinus complaints & 12 & 42 & 36 & 11 & .0590 \\
\hline Throat irritation & 14 & 20 & 32 & 16 & .1192 \\
\hline Dermat it is & 12 & 19 & 23 & 30 & .5770 \\
\hline Sweet taste of cigarettes & 31 & 55 & 60 & 78 & .0004 \\
\hline Nocturia & 6 & 77 & 19 & 30 & .0779 \\
\hline
\end{tabular}


Table 12

Respiratory Symptoms Among Southwire Employees

by Place and Smoking Habit, 1978

Southwire Company, Incorporated

Carroliton, Georgia

October $4-11,1978$

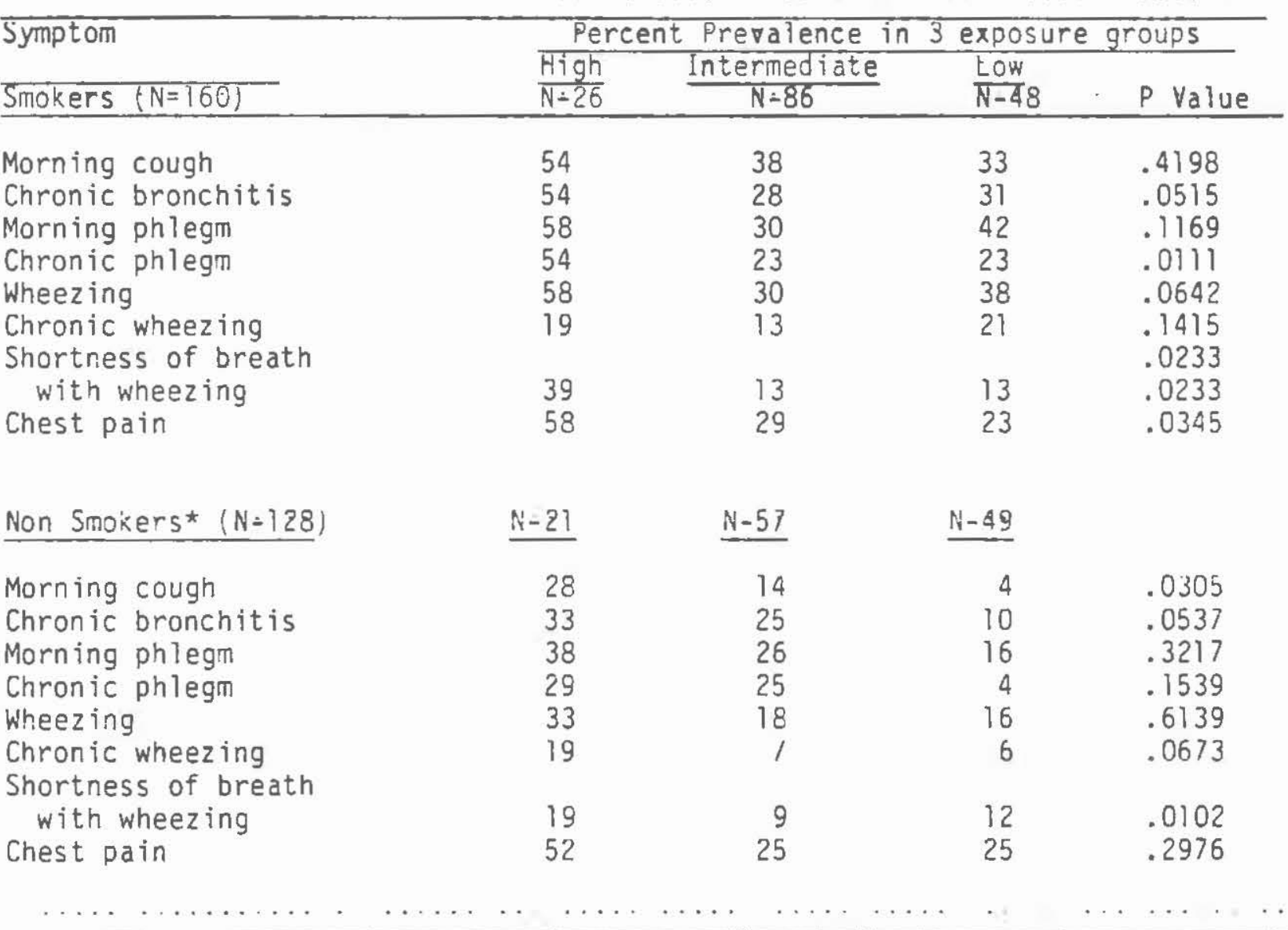

* Includes 41 ex-cigarette smokers 
Table 13

Prevalence of Hypertension in Male Southwire Employees

by Race and Age, 1978, as Compared to Rates

for the U.S. Population, 1971-1974 (16)

Southwire Company, Incorporated

Carroliton, Georgia

October $4-11,1978$

\begin{tabular}{|c|c|c|c|c|}
\hline Age & Observed & $\begin{array}{l}\text { Observed Rate } \\
\text { Per } 100 \text { Persons }\end{array}$ & $\begin{array}{l}\text { Expected Rate } \\
\text { Per } 100 \text { Persons }\end{array}$ & $\begin{array}{l}\text { Observed } \\
\text { Expected }\end{array}$ \\
\hline $\begin{array}{l}\text { White } \\
\text { T8-24 } \\
25-34 \\
35-44 \\
45-54 \\
55-64 \\
\text { Total } 18-64\end{array}$ & $\begin{array}{l}11 / 68 \\
31 / 83 \\
18 / 37 \\
10 / 16 \\
1 / 3 \\
71 / 207\end{array}$ & $\begin{array}{l}16.2 \\
37.3 \\
48.6 \\
62.5 \\
33.3 \\
34.3\end{array}$ & $\begin{array}{l}19.6 \\
27.6 \\
35.9 \\
53.3 \\
58.0 \\
28.7\end{array}$ & $\begin{array}{l}0.8 \\
1.4 \\
1.4 \\
1.2 \\
0.6 \\
1.2\end{array}$ \\
\hline $\begin{array}{l}\frac{81 \text { ack }}{18-24} \\
25-34 \\
35-44 \\
45-54 \\
55-64 \\
\text { Total } 13-64\end{array}$ & $\begin{array}{l}6 / 19 \\
17 / 30 \\
5 / 12 \\
6 / 7 \\
3 / 4 \\
37 / 72\end{array}$ & $\begin{array}{l}31.6 \\
56.7 \\
41.7 \\
85.7 \\
75.0 \\
51.4\end{array}$ & $\begin{array}{l}15.2 \\
35.4 \\
60.6 \\
53.8 \\
68.0 \\
33.8\end{array}$ & $\begin{array}{l}2.1 \\
1.6 \\
0.7 \\
1.6 \\
1.1 \\
1.5 \star\end{array}$ \\
\hline$\frac{\text { Both } \cdot \text { Races }}{18-64 \ldots}$ & $108 / 279$ & 38.7 & 30.0 & $1.3^{\star \star}$ \\
\hline
\end{tabular}


Table 13a

Prevalence of Borderline Hypertension in Male Southwire Employees

by Age and Race, 1978, Compared to Rates for U.S. Population, 1971 - $1974(16)$

Southwire Company, Incorporated

Carrollton, Georgia

October $4-11,1978$

\begin{tabular}{|c|c|c|c|c|}
\hline Age & Observed & $\begin{array}{l}\text { Observed Rate } \\
\text { Per } 100 \text { Persons }\end{array}$ & $\begin{array}{l}\text { Expected Rate } \\
\text { Per } 100 \text { Persons }\end{array}$ & $\frac{\text { Observed }}{\text { Expected }}$ \\
\hline $\begin{array}{l}\frac{\text { White }}{18-24} \\
25-34 \\
35-44 \\
45-54 \\
55-64 \\
\text { Total } 18-64\end{array}$ & $\begin{array}{c}6 / 68 \\
23 / 83 \\
8 / 37 \\
6 / 16 \\
0 / 3 \\
43 / 207\end{array}$ & $\begin{array}{r}8.8 \\
27.8 \\
21.6 \\
37.5 \\
0.0 \\
20.8\end{array}$ & $\begin{array}{l}14.7 \\
19.4 \\
18.6 \\
27.5 \\
26.9 \\
18.4\end{array}$ & $\begin{array}{l}0.6 \\
1.4 \\
1.2 \\
1.4 \\
0 \\
1.1\end{array}$ \\
\hline $\begin{array}{l}\frac{B 1 a c k}{18-24} \\
25-34 \\
35-44 \\
45-54 \\
55-64 \\
\text { Total 18-64 }\end{array}$ & $\begin{array}{l}3 / 19 \\
6 / 30 \\
1 / 12 \\
3 / 7 \\
1 / 4 \\
14 / 72\end{array}$ & $\begin{array}{r}15.8 \\
20.0 \\
8.3 \\
42.9 \\
25.0 \\
19.4\end{array}$ & $\begin{array}{l}10.6 \\
17.1 \\
22.4 \\
17.0 \\
18.1 \\
16.6\end{array}$ & $\begin{array}{l}1.5 \\
1.1 \\
0.4 \\
2.5 \\
1.4 \\
1.2\end{array}$ \\
\hline Both Races & & & & \\
\hline $18-64$ & $57 / 279$ & 20.4 & 17.9 & 1.1 \\
\hline.$\quad \ldots \ldots$ & . . & . . . $=$ & . . & 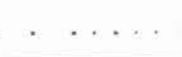 \\
\hline
\end{tabular}




\begin{tabular}{|c|c|c|c|c|}
\hline \multicolumn{5}{|c|}{$\begin{array}{r}\begin{array}{r}\text { Prevalence of Definite Hypertension in Male Southw } \\
\text { Race and Age, 1978, Compared to Rates for The U. } \\
1971-1974(16)\end{array} \\
\text { Southwire Company, Incorporated } \\
\text { Carrollton, Georgia } \\
\text { October 4-11, 1978 }\end{array}$} \\
\hline Age & Observed & $\begin{array}{l}\text { Observed Rate } \\
\text { Per } 100 \text { Persons }\end{array}$ & $\begin{array}{l}\text { Expected Rate } \\
\text { Per } 100 \text { Persons }\end{array}$ & Exserved \\
\hline $\begin{array}{l}\text { White } \\
\text { 18-24 } \\
25-34 \\
35-44 \\
45-54 \\
55-64 \\
\text { Total } 18-64\end{array}$ & $\begin{array}{c}5 / 68 \\
8 / 83 \\
10 / 37 \\
4 / 16 \\
1 / 3 \\
28 / 207\end{array}$ & $\begin{array}{r}7.4 \\
9.6 \\
27.0 \\
25.0 \\
33.3 \\
13.5\end{array}$ & $\begin{array}{r}4.9 \\
8.2 \\
17.3 \\
25.8 \\
31.1 \\
10.3\end{array}$ & $\begin{array}{l}1.5 \\
1.2 \\
1.6 \\
1.0 \\
1.1 \\
1.3\end{array}$ \\
\hline $\begin{array}{l}\text { Black } \\
18-24 \\
25-34 \\
35-44 \\
45-54 \\
55-64 \\
\text { Total } 18-64\end{array}$ & $\begin{array}{c}3 / 19 \\
11 / 30 \\
4 / 12 \\
3 / 7 \\
2 / 4 \\
23 / 72\end{array}$ & $\begin{array}{l}15.8 \\
36.7 \\
33.3 \\
42.8 \\
50.0 \\
31.9\end{array}$ & $\begin{array}{r}4.6 \\
17.7 \\
38.2 \\
36.8 \\
49.9 \\
21.9\end{array}$ & $\begin{array}{l}3.4 \\
2.1 \\
0.9 \\
1.2 \\
1.0 \\
1.5\end{array}$ \\
\hline$\frac{\text { Both Races }}{\text { Total } 18-64}$ & $\begin{array}{r}51 / 279 \\
\cdots \quad \cdots \\
\end{array}$ & $\ldots 18.3 \quad \ldots$ & $\begin{array}{c}13.3 \\
\ldots \ldots\end{array}$ & $\begin{array}{c}1.4^{*} \\
\cdots \cdots\end{array}$ \\
\hline
\end{tabular}

$\star p<.05$ 
Table $13 \mathrm{c}$

Prevalence of Blood Pressure of at least $105 \mathrm{~mm} \mathrm{Hg}$ Diastolic Among Male Southwire. Employees by Race and Age, 1978,

Compared to Rates for U.S. Population 1971-1974 (16)

Southwire Company
Carrollton, Georgia

October $4-11,1978$

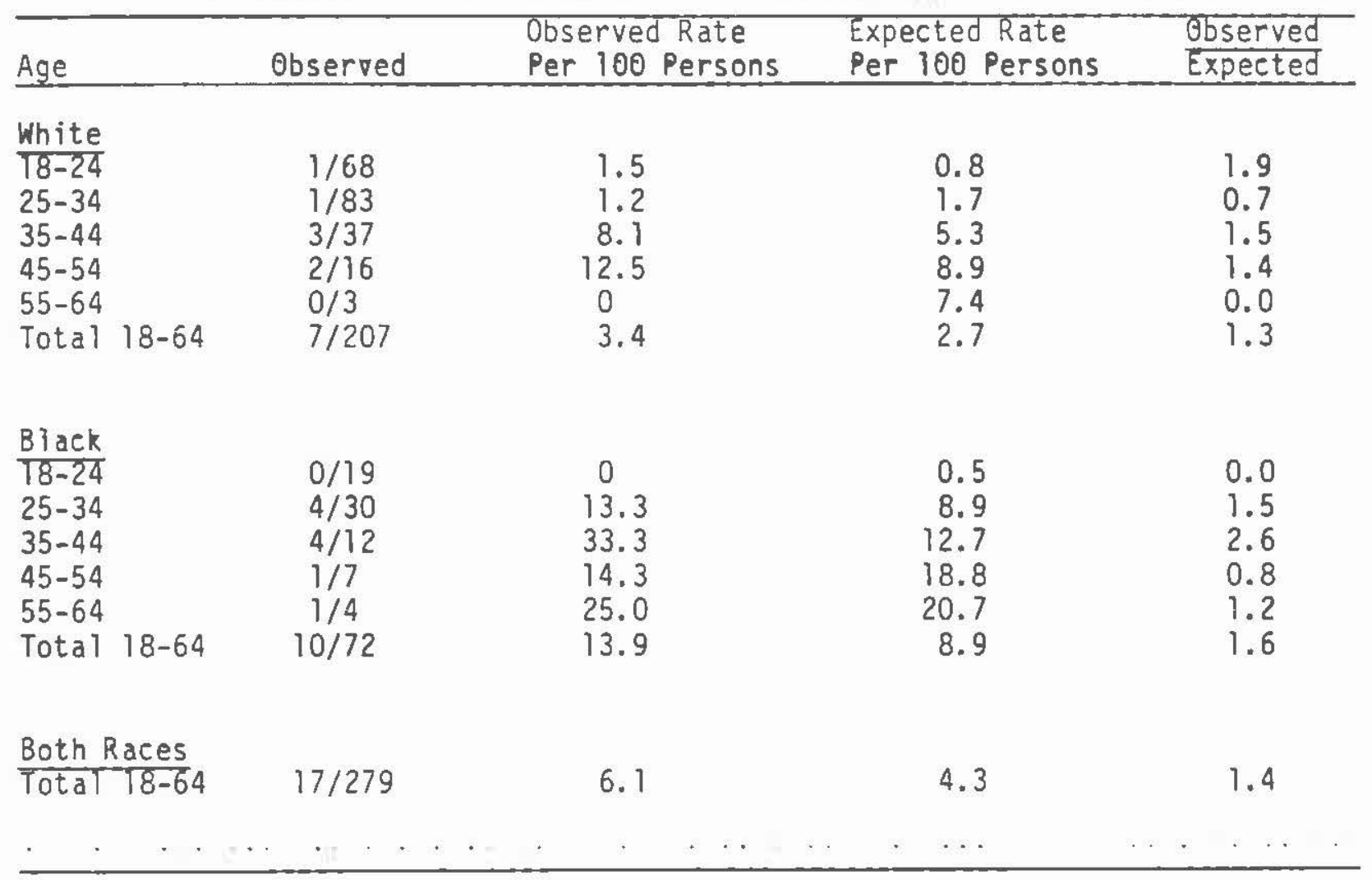


Table 13d

Systolic and Diastolic Blood Pressure of Male Southwire

Employees by Age and Race, 1978, Compared to Means in southern Male U.S. Population, 1971 - 1974 (16)

Southwire Company, Incorporated
Carrollton, Georgia

October 4-11, 1978

\begin{tabular}{|c|c|c|c|c|c|}
\hline Age & $\begin{array}{l}\text { No. of } \\
\text { Employees }\end{array}$ & $\begin{array}{l}\text { Mean } \\
\text { Stystolic } \\
\text { and S.O. }\end{array}$ & $\begin{array}{l}\text { Expected } \\
\text { Mean }\end{array}$ & $\begin{array}{l}\text { Mean } \\
\text { Diastolic } \\
\text { and S.D. }\end{array}$ & Expected Mean \\
\hline $\begin{array}{l}\text { White } \\
8-24 \\
25-34 \\
35-44 \\
45-54 \\
55-64\end{array}$ & $\begin{array}{r}68 \\
83 \\
37 \\
16 \\
3\end{array}$ & $\begin{array}{l}124.8+10.7 \\
128.5 \pm 13.2 \\
131.4+14.0 \\
134.3 \mp 15.2 \\
134.3 \pm 18.3\end{array}$ & $\begin{array}{l}125.0 \\
128.7 \\
128.0 \\
135.7 \\
139.8\end{array}$ & $\begin{array}{l}78.6 \pm 10.7 * \\
83.1 \mp 9.6 \\
86.0 \mp 13.7 \\
90.5 \mp 12.0 \\
86.0 \pm 12.0\end{array}$ & $\begin{array}{l}75.7 \\
81.7 \\
83.8 \\
88.5 \\
87.1\end{array}$ \\
\hline Total 18-64 & 201 & $128.2 \pm 13.0$ & 128.0 & $82.8 \pm 11.4 * *$ & 80.7 \\
\hline $\begin{array}{l}\frac{B 1 a c k}{18-24} \\
25-34 \\
35-44 \\
45-54 \\
55-64\end{array}$ & $\begin{array}{r}19 \\
30 \\
12 \\
7 \\
4\end{array}$ & $\begin{array}{l}127.9 \pm 9.6 \\
137.4 \mp 16.4^{\star \star} \\
134.0 \mp 20.6 \\
137.4 \mp 15.9 \\
137.5^{2} \mp 17.5\end{array}$ & $\begin{array}{l}124.2 \\
129.1 \\
137.6 \\
141.3 \\
143.7\end{array}$ & $\begin{array}{l}83.3+9.6 * \\
89.6 \mp 13.0^{\star} \\
90.1 \mp 16.2 \\
93.1 \mp 10.3 \\
91.8 \mp 14.4\end{array}$ & $\begin{array}{l}77.3 \\
84.0 \\
90.6 \\
93.1 \\
92.7\end{array}$ \\
\hline Total 18-64 & 72 & $134.3+15.8$ & 131.2 & $88.5+12 . *$ & 84.7 \\
\hline$\frac{\text { Both } \cdot \text { Race }}{18-64}$ & $279 \ldots$ & $129.8+14.0$ & $128.8 \ldots$ & $\begin{array}{c}84.2+72.0 * \star \star \\
\ldots \ldots\end{array}$ & 81.7 \\
\hline
\end{tabular}

* $p<.05 \quad 2$ tailed t test

$\star \quad p<.01$

$\star \star \star x \quad p<.001$ 
Table 14

Abnormal Neurologic Findings Anong Southwire Employees by Lead Level, 1978

Southwire Company, Incorporated

Carrollton, Georgia

October $4-11,1978$

\begin{tabular}{|c|c|c|c|c|c|}
\hline Nearologic Abnormality & $\begin{array}{l}\frac{\text { Percent }}{20} \\
\square=49\end{array}$ & $\begin{array}{l}\text { prevalence } \\
21-40 \\
N=126\end{array}$ & $\begin{array}{l}\text { in } \frac{1}{\text { lead }} \\
41-60 \\
W=84\end{array}$ & $\begin{array}{l}\text { groups: } \\
60 \\
N=27\end{array}$ & $\frac{(0 g \%)}{p \text { Value }}$ \\
\hline $\begin{array}{l}\text { Hyporeflexia: } \\
\text { Achilles tendon } \\
\text { Biceps tendon } \\
\text { Brochioradialis } \\
\text { Quadriceps }\end{array}$ & $\begin{array}{r}4.1 \\
6.1 \\
10.2 \\
8.2\end{array}$ & $\begin{array}{r}7.9 \\
12.7 \\
16.7 \\
7.9\end{array}$ & $\begin{array}{l}14.3 \\
22.6 \\
23.8 \\
16.7\end{array}$ & $\begin{array}{r}25.9 \\
11.1 \\
11.1 \\
3.7\end{array}$ & $\begin{array}{l}.0128 \star \star \star \\
.0484 \star \star \star \\
.1716 \\
.1099\end{array}$ \\
\hline $\begin{array}{l}\text { Decreased Muscle } \\
\text { Strength: } \\
\text { Finger extensors } \\
\text { Wrist extensors } \\
\text { Ankle dorsiflexors }\end{array}$ & $\begin{array}{l}0.0 \\
2.0 \\
2.0\end{array}$ & $\begin{array}{l}1.6 \\
0.8 \\
0.8\end{array}$ & $\begin{array}{l}4.8 \\
2.4 \\
1.2\end{array}$ & $\begin{array}{l}7.4 \\
3.7 \\
3.7\end{array}$ & $\begin{array}{l}.1477^{\star \star} \\
.6891 \\
.6803\end{array}$ \\
\hline $\begin{array}{l}\text { Abnormal sensory-motor findings } \\
\text { Adiadochokinesia } \\
\text { Abnormal finger to nose test } \\
\text { Hand tremor }\end{array}$ & $\begin{array}{l}0.0 \\
0.0 \\
8.2\end{array}$ & $\begin{array}{r}3.2 \\
5.6 \\
11.1\end{array}$ & $\begin{array}{r}8.3 \\
9.5 \\
15.5\end{array}$ & $\begin{array}{r}22.2 \\
3.7 \\
18.5\end{array}$ & $\begin{array}{c}.0004^{\star} \\
.1361 \\
.4537\end{array}$ \\
\hline$\ldots \quad \ldots \quad \ldots \ldots, \ldots \ldots \ldots \ldots, \ldots$ & $\cdot \ldots \ldots$ & . . . & . . . & . $\ldots$ & $\ldots \ldots, \ldots$ \\
\hline
\end{tabular}

* Significant by grouped EP ( $\leq 800,>300 \mathrm{ug} / 7$ erythrocytes $)$ at $p<.01$

** significant by grouped EP at $p<.05$

$\star \star \star$ not significant by grouped EP 


\section{Table $15 a$}

Mean Erythrocyte Protoporphyrin and Creatinine for Four Groups of Blood Lead Levels, Southwire Copper Division, 1978

Southwire Company, Incorporated

Carrollton, Georgia

October $4-11,1978$

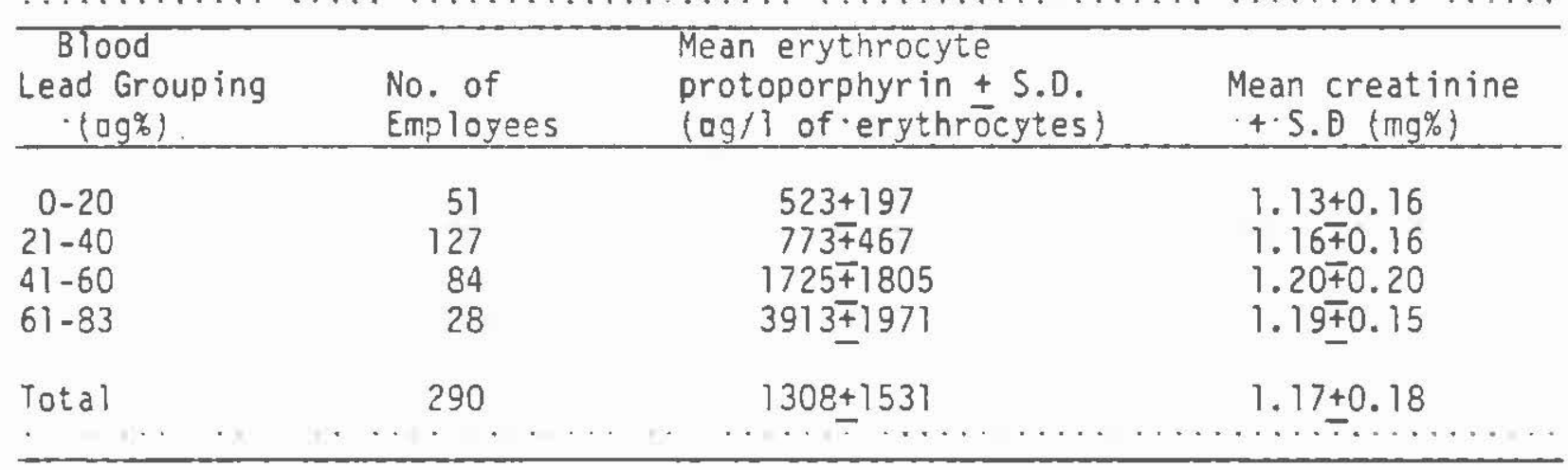


Table 15b

Mean Blood Lead and Erythrocyte Protoporphyrin by Work Area and Shift, Southwire Copper Division, 1978

Southwire Company, Incorporated Carrollton, Georgia

October $4-11,1978$

\begin{tabular}{|c|c|c|c|}
\hline Shift & $\begin{array}{l}\text { No. of } \\
\text { Employees }\end{array}$ & $\begin{array}{l}\text { Mean Lead } \\
+5.0 \cdot(02 \%) \\
\end{array}$ & $\begin{array}{l}\text { Mean erythrocyte } \\
\text { protoporphyrin } 4 \text { S.D. } \\
\text { (ag/l of erythrocytes) }\end{array}$ \\
\hline $\begin{array}{l}\text { High Exposure } \\
7 a m-3 p m \\
3 p m-11 p m \\
11 p m-7 a m \\
8 a m-8 p m\end{array}$ & $\begin{array}{r}48 \\
18 \\
16 \\
12 \\
2\end{array}$ & $\begin{array}{l}61.8+12.2 \\
60.3 \pm 12.5 \\
57.4412 .9 \\
69.7 \pm 7.9 \\
63.5 \pm 6.4\end{array}$ & $\begin{array}{l}3736+2330 \\
3139 \mp 1874 \\
5108+2820 \\
3201 \mp 1456 \\
1331 \pm 1200\end{array}$ \\
\hline $\begin{array}{l}\text { Intermediate Exposure } \\
7 a m-7 p m \\
3 p m-11 p m \\
11 p m-7 a m \\
8 a m-8 p m \\
8 p m-8 a m\end{array}$ & $\begin{array}{r}141 \\
62 \\
11 \\
13 \\
48 \\
7\end{array}$ & $\begin{array}{l}38.4+11.0 \\
35.9 \pm 11.4 \\
31.8 \mp 7.5 \\
42.0 \mp 12.4 \\
42.1 \mp 10.0 \\
39.9 \pm 5.0\end{array}$ & $\begin{array}{l}1024+683 \\
886 \pm 520 \\
987 \mp 393 \\
1241 \mp 787 \\
1104+736 \\
1362 \mp 1386\end{array}$ \\
\hline $\begin{array}{l}\text { Low Exposare } \\
\text { 7am-3pm } \\
3 p m-11 p m \\
11 p m-7 a m \\
8 a 7-8 p m \\
3 p m-3 a m\end{array}$ & $\begin{array}{r}99 \\
82 \\
6 \\
1 \\
6 \\
4\end{array}$ & 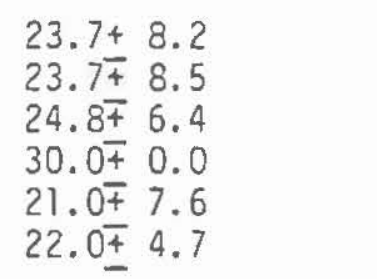 & $\begin{array}{r}547+208 \\
548+217 \\
500 \mp 1112 \\
1006 \overline{+0.0} \\
524 \overline{7} 142 \\
481 \pm 115\end{array}$ \\
\hline $\begin{array}{l}\text { Total by Shift } \\
7 a m-3 p m \\
3 p m-11 p m \\
11 p m-/ a m \\
8 a m-8 p m \\
8 p m-8 a m \\
\ldots \ldots\end{array}$ & $\begin{array}{r}288 \\
162 \\
33 \\
26 \\
56 \\
11\end{array}$ & $\begin{array}{l}37.2+16.4 \\
32.4+15.2 \\
42.9477 .6 \\
54.3+17.8 \\
40.6 \mp 12.5 \\
33.4 \div 10.1\end{array}$ & $\begin{array}{r}1308+1531 \\
965^{+} 1057 \\
2897 \pm 2925 \\
2137 \mp 1498 \\
1050+726 \\
1042+1163 \\
\quad\end{array}$ \\
\hline
\end{tabular}


Table 15c

Mean Blood Lead and Erythrocyte Protoporphyrin by

Job Class and Place, Southwire Copper Division, 1978

Southwire Company, Incorporated

Carrollton, Georgia

October 4-11, 1978

\begin{tabular}{|c|c|c|c|}
\hline Job Elass & $\begin{array}{l}\text { No. of } \\
\text { Emp loyees }\end{array}$ & $\begin{array}{l}\text { Mean Lead } \\
+5.0 \text {. } \\
\text { Fog } \%\end{array}$ & $\begin{array}{l}\text { Mean Erythrocyte } \\
\text { Protoporphyrin } \pm \text { S.D. } \\
\text { (ug/1 of erythrocytes) }\end{array}$ \\
\hline पigh Exposare & 48 & $61.8+12.2$ & $3736+2330$ \\
\hline Supervisory & 9 & $61.0 \mp 11.9$ & $3067 \overline{7} 1349$ \\
\hline Industrial & 39 & 62.0472 .4 & $3890 \mp 2491$ \\
\hline \multicolumn{4}{|l|}{ Intermediate } \\
\hline \multirow{4}{*}{$\begin{array}{l}\text { Exposure } \\
\text { office } \\
\text { Supervisory } \\
\text { Industrial }\end{array}$} & 141 & $38.4+11.0$ & $1024+683$ \\
\hline & 14 & $30.0 \pm 12.4$ & $857 \mp 681$ \\
\hline & 22 & $32.6 \pm 9.8$ & $982 \overline{4} 597$ \\
\hline & 105 & $40.8 \mp 10.1$ & $1056 \Phi 702$ \\
\hline Low Exoosare & 100 & $23.7 \pm 8.2$ & $547+208$ \\
\hline office & 39 & $20.1 \mp 7.2$ & $515 \mp 159$ \\
\hline Supervisory & 7 & $22.7 \mp 7.3$ & $511 \overline{ \pm} 115$ \\
\hline Industrial & 54 & $26.4 \bar{\Psi} 8.0$ & $574 \overline{ \pm} 245$ \\
\hline Total by Job Elass & & $37.2+16.5$ & $1308+1531$ \\
\hline Office & 53 & $22.7 \mp 9.8$ & $605 \mp 397$ \\
\hline Supervisory & 38 & $37.5 \overline{1} 6.8$ & $1389 \mp 1236$ \\
\hline Industrial & 198 & $41.0 \mp 75.7$ & $1483 \overline{7} 716$ \\
\hline
\end{tabular}


Table 15d

Mean Blood Lead and Erythrocyte Protoporphyrin by

Smoking Habit and Place, Southwire Copper Division, 1978

Southwire Company, Incorporated

Carrollton, Georgia

October $4-11,1978$

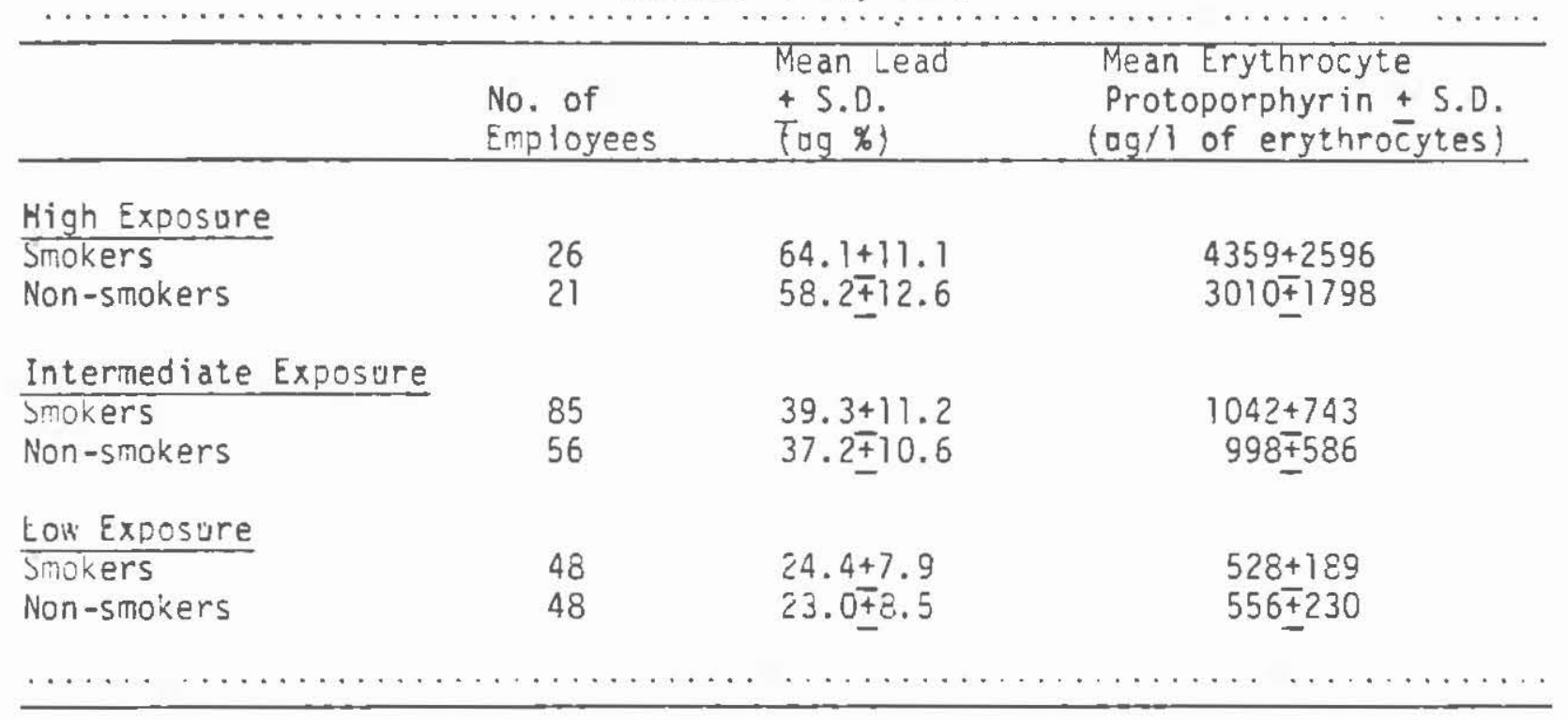


APPENDIX I

\section{ENVIRONMENTAL EVALUATION CRITERIA*}

Southwire Company, Incorporated

Carrollton, Georgia

October 2-6, 1978

\begin{tabular}{|c|c|c|c|c|}
\hline SUBSTANCE & $\begin{array}{l}\text { NIOSH } \\
\text { RECUMMENOEO STANEARO }\end{array}$ & SOUREE & OSHA. STANEARE & SOUREE \\
\hline Inorganic Lead & $50 \mathrm{ug} / \mathrm{M}^{3}$ & Reference 6 & $\star \star 50-200 \mathrm{ug} / \mathrm{M}^{3}$ & Reference \\
\hline Inorganic Lead & $2 \mathrm{ug} / \mathrm{M}^{3}$ & Peference 4 & $10 \mathrm{ug} / \mathrm{M}^{3}$ & Reference \\
\hline Inorganii vizkel & 15 ия/ 3 & Peference 5 & 1000 ug/: $:^{3}$ & $R \in$ ference \\
\hline Copper Justs & $\ldots-\cdots$ & 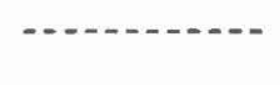 & 1000 ug/:3 & Reference \\
\hline Copder Fur.e & ---- & - & $100 \mathrm{ug} / \mathrm{m}^{3}$ & Reference \\
\hline ladmium & 40 ug $/:^{3}$ & Reference 9 & $200 \mathrm{ug} / \mathrm{M}^{3}$ & Reference \\
\hline Zinc 0xije Fume & $5000 \mathrm{ug} / \mathrm{M}^{3}$ & Reference 10 & $5000 \mathrm{ug} / \mathrm{M}^{3}$ & Reference \\
\hline Suifuric ACid & 1000 ug/: 3 & Peference 11 & $1000 \mathrm{ug} / \mathrm{M}^{3}$ & Reference \\
\hline Carbon Monoxide & $35 \mathrm{ppm}$ & Reference 12 & $50 \mathrm{ppm}$ & Reference \\
\hline
\end{tabular}

* The iIUSH criteria refer to the Time-Weighted Average (TWA) concentrations for up to a 10-hour workday, 40-hour workweek, except that for Inorganic Arsenic which is a ceiling concentration. The USHA standards or Permissible Exposure Limits (PEL's) refer to a TWA concentration for an 8-hour workday, 40-hour workweek.

** The 8-hour TWA PEL for inorganic lead has been reduced from $200 \mathrm{ug} / \mathrm{M}^{3}$ to $50 \mathrm{ug} / \mathrm{M}^{3}$ (29 CFR 1910.1025). Pending current litigation of the $50 \mathrm{ug} / \mathrm{M}^{3}$ lead standard, employers must achieve the $200 \mathrm{ug} / \mathrm{M}^{3}$ level through engineering and administrative controls, and must protect workers at the $50 \mathrm{ug} / \mathrm{M}^{3} \mathrm{PEL}$ through any combination of controls, including the use of proper respirators. 


\section{APPENDIX II}

Baqhouse Operations - Personal Exposures to Metallic Aerosols

Southwire Companv. Inc.

Carrollton, Georaia

October $3-5,1978$

\begin{tabular}{|c|c|c|c|c|c|c|c|}
\hline Date & Worker & $\begin{array}{l}\text { Total Sample Time } \\
\text { Hours }\end{array}$ & एead & $\frac{\text { Airborne }}{\text { Conper }}$ & $\frac{\text { Conce }}{\text { Linc }}$ & $\frac{\text { ntration }}{\text { Nickel }}$ & $\frac{-u q / M^{3}}{\text { Cadmium }}$ \\
\hline $\begin{array}{l}10-3 \\
10-5\end{array}$ & $\begin{array}{l}\text { Baqhouse Attendant No. } 1 \\
\text { Baqhouse Attendant No. } 1\end{array}$ & $\begin{array}{l}7.42 \\
7.85\end{array}$ & $\begin{array}{l}164 \\
105\end{array}$ & $\begin{array}{l}179 \\
120\end{array}$ & $\begin{array}{l}595 \\
368\end{array}$ & $\begin{array}{l}9.0 \\
4.3\end{array}$ & $\begin{array}{l}4.5 \\
\angle L D^{A}\end{array}$ \\
\hline $\begin{array}{l}10-3 \\
10-4 \\
10-5\end{array}$ & $\begin{array}{l}\text { Baqhouse Attendant No. } 2 \\
\text { Baqhouse Attendant No. } 2 \\
\text { Baqhouse Attendant No. }\end{array}$ & $\begin{array}{l}6.19 \\
7.83 \\
7.85\end{array}$ & $\begin{array}{r}2012 \\
184 \\
991\end{array}$ & $\begin{array}{l}790 \\
156 \\
467\end{array}$ & $\begin{array}{r}8446 \\
624 \\
3822\end{array}$ & $\begin{array}{l}\text { LLD } \\
5.7 \\
\text { LLD }\end{array}$ & $\begin{array}{r}45 \\
\text { LLU } \\
24\end{array}$ \\
\hline $\begin{array}{l}10-3 \\
10-4\end{array}$ & $\begin{array}{l}\text { Baqhouse Attendant No. } 3 \\
\text { Baqhouse Attendant No. } 3\end{array}$ & $\begin{array}{l}7.25 \\
5.33\end{array}$ & $\begin{array}{l}129 \\
271\end{array}$ & $\begin{array}{r}80 \\
333\end{array}$ & $\begin{array}{l}536 \\
854\end{array}$ & $\begin{array}{l}\text { LLD } \\
\text { LLD }\end{array}$ & $\begin{array}{l}3.1 \\
6.3\end{array}$ \\
\hline $\begin{array}{l}10-4 \\
10-5 \\
10-4\end{array}$ & $\begin{array}{l}\text { Baahouse Attendant No. } 4 \\
\text { Baahouse Attendant No. } 4 \\
\text { Baahouse Attendant No. } 5\end{array}$ & $\begin{array}{l}7.83 \\
7.92 \\
6.67\end{array}$ & $\begin{array}{r}82 \\
182 \\
283\end{array}$ & $\begin{array}{r}88 \\
118 \\
233\end{array}$ & $\begin{array}{l}298 \\
604 \\
850\end{array}$ & $\begin{array}{l}4.3 \\
\text { LLD } \\
\text { LLD }\end{array}$ & $\begin{array}{l}\text { LLD } \\
5.6 \\
6.7\end{array}$ \\
\hline
\end{tabular}

A Lower Limit of Detection. The LLD for nickel and cadmium is 3 and 2 uq der sample. respectively. 
APPENDIX III

Blast/Converter Furnace Areas - Personal Exposures to Metallic Aerosols

Southwire Company, Inc.

Carrollton. Georaia

October $3-5,1978$

\begin{tabular}{|c|c|c|c|c|c|c|c|}
\hline \multirow[b]{2}{*}{ Date } & \multirow[b]{2}{*}{ Worker } & \multirow{2}{*}{$\begin{array}{c}\text { Sample Time } \\
\text { Hours }\end{array}$} & \multicolumn{5}{|c|}{ Airborne Concentration - va/ $/ \mathrm{m}^{3}$} \\
\hline & & & Lead & CODDer & $\operatorname{Zinc}$ & Nickel & Cacmium \\
\hline $10-4$ & Hot Metals Asst. No. 1 & 7.90 & 183 & 120 & 1688 & LLDA & LLD \\
\hline $10-5$ & Hot Metals Asst. No. 1 & 7.83 & 212 & 270 & 511 & LLD & LLD \\
\hline $10-3$ & Hot Metals Asst. No. 2 & 7.68 & 127 & 607 & 202 & LLD & LLO \\
\hline $10-3$ & Hot Metals Asst. No. 3 & 5.28 & 180 & 988 & 1304 & LLD & LLD \\
\hline $10-4$ & hot Metals Asst. iNo. 3 & 7.90 & 103 & 169 & 478 & LLD & LLD \\
\hline $10-3$ & Hot Metals Asst. No. 4 & 7.80 & 70 & 299 & 199 & 4.3 & LLD \\
\hline $10-5$ & Hot Metals Asst. No. 4 & 3.00 & 114 & 153 & 153 & LLD & LLD \\
\hline $10-3$ & Blast Furnace Charaer & 7.75 & 105 & 344 & 387 & LLD & LLD \\
\hline $10-4$ & Blast Furnace Charaer & 7.98 & 86 & 153 & 292 & LLD & LLD \\
\hline $10-5$ & Blast Furnace Charqer & 8.03 & 166 & 373 & 526 & 5.5 & 2.8 \\
\hline
\end{tabular}

ALower Limit of Getection. The LLD for nickel and cadmium is 3 and 2 uq per sample, respectively. 


\section{APPENDIX IV}

Personal Exposures to Metallic Aerosols by Laborers Involved with Tear Down of the Maerz Furnace

Southwire Company, Inc. Carrollton, Georaia

October 3-4. 1978

\begin{tabular}{|c|c|c|c|c|c|c|c|}
\hline \multirow[b]{2}{*}{ Date } & \multirow[b]{2}{*}{ Worker } & \multirow{2}{*}{$\begin{array}{c}\text { Sample Time } \\
\text { Hours }\end{array}$} & \multicolumn{5}{|c|}{ Airborne Concentration - Ua/M3 } \\
\hline & & & Lead & Copper & $\operatorname{lnnc}$ & NickeT & Cadmivm \\
\hline $10-3$ & Laborer No. 2 & 10.60 & 78 & 979 & 153 & 4.1 & LLDA \\
\hline $10-3$ & Laborer No. 3 & 10.80 & 77 & 854 & 192 & 7.1 & LLD \\
\hline $10-4$ & Laborer No. 4 & 9.95 & 221 & 2702 & 435 & 8.7 & 3.3 \\
\hline $10-4$ & Laborer No. 6 & 10.38 & 91 & 438 & 221 & 5.5 & LLD \\
\hline
\end{tabular}

ALower Limit of Detection. The LLD for nickel and cadmium is 3 and 2 uq Der sample, respectivelv. 


\section{APPENDIX V}

Exposures to Metallic Aerosols by Laborers while Cleaning the Maerz Furnace Waste-Heat Boiler (Economizer)

Copper Division of Southwire

Southwire Company, Inc.

Carrollton, Georgia

October 3 and 4,1978

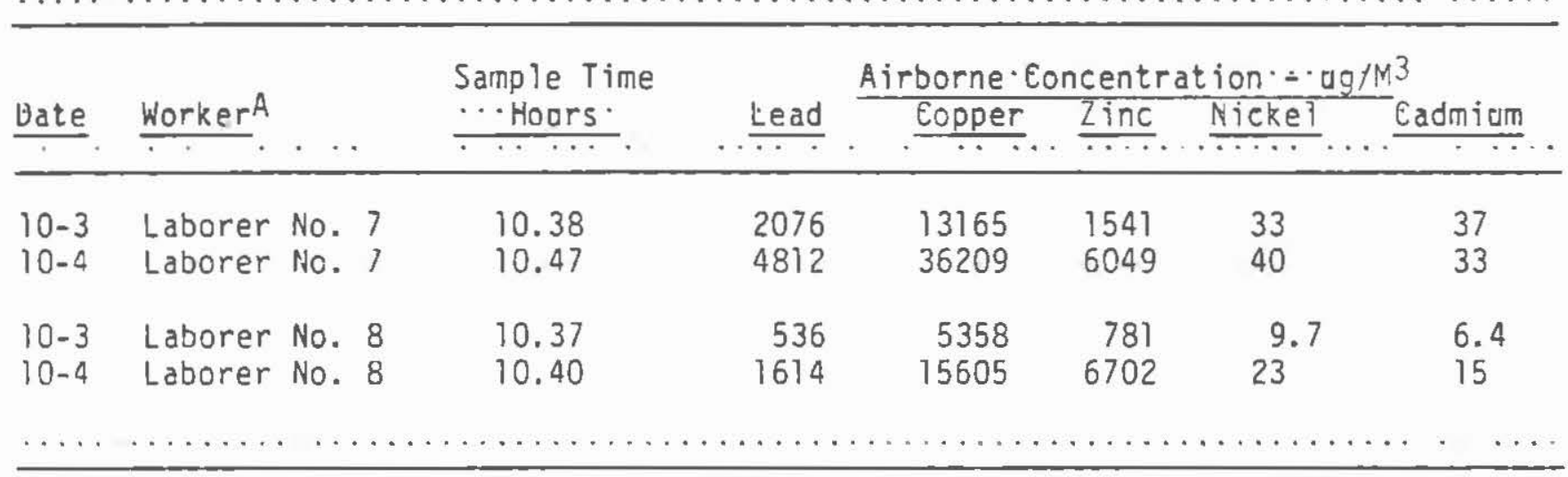

ASamples were collected at external surface of person wearing a half-face or an air-line supplied respirator. The type of respirator worn varied during the workday depending on the nature of the worker's cleaning responsibility; i.e., the worker wore the air-line supplied respirator when he blew dust off the heat exchanger fins. 


\title{
APPENDIX VI
}

\author{
Samplinq Area - Personal Exposures to Metallic Aerosols \\ Southwire Company, Inc. \\ Carrollton, Georqua \\ October $4-5,1978$
}

\begin{tabular}{|c|c|c|c|c|c|c|c|}
\hline \multirow[b]{2}{*}{ Date } & \multirow[b]{2}{*}{ Worker } & \multirow{2}{*}{$\begin{array}{l}\text { Sample Time } \\
\text { Hours }\end{array}$} & \multicolumn{5}{|c|}{ Airborne Concentration - uq/M3 } \\
\hline & & & Lead & Copper & Zinc & Nickel & Cadmium \\
\hline $10-4$ & Furnace Oderator & 6.42 & 47 & 260 & 190 & LLDA & LLD \\
\hline $10-4$ & Furnace Tender & 7.75 & 46 & 846 & 215 & 4.3 & LLD \\
\hline $10-5$ & Weiaher & 7.92 & 34 & 491 & 224 & LLD & LLD \\
\hline
\end{tabular}

ALower Limit of Detection. The LLD for nickel and cadmium is 3 and 2 ua der sample, respectivelv. 
APPENDIX VII

Scrap Handlina (Bedyard) - Personal Exposures to Metallic Aerosols

Southwire Combany, Inc.

Carrollton. Georaia

October 3-5. 1978

\begin{tabular}{|c|c|c|c|c|c|c|c|}
\hline \multirow[b]{2}{*}{ Date } & \multirow[b]{2}{*}{ Worker } & \multirow{2}{*}{$\begin{array}{c}\text { Sample Time } \\
\text { Hours }\end{array}$} & \multicolumn{5}{|c|}{ Airborne Concentration $-\mathrm{ug} / \mathrm{M}^{3}$} \\
\hline & & & Lead & Copper & Zinc & Nickel & Cadmium \\
\hline $10-3$ & Small Equipment Auxillarv Operator & 11.27 & 192 & 4158 & 260 & 2.9 & LLDA \\
\hline $10-4$ & Small Equipment Auxillary Operator & 9.83 & 38 & 259 & 330 & 9.0 & LLD \\
\hline $10-5$ & Small Equipment Auxillary Operator & 9.10 & 60 & 244 & 220 & LLD & LLD \\
\hline $10-3$ & Larqe Equipment Auxillary Operator & 11.40 & 360 & 1590 & 1190 & 16 & 6.5 \\
\hline $10-4$ & Larqe Equipment Auxillary Operator & 9.93 & 43 & 257 & 123 & 5.6 & LLD \\
\hline $10-3$ & Larqe Equipment Auxillary Operator & 11.25 & 36 & 191 & 117 & 4.7 & LLD \\
\hline $10-4$ & Larqe Equipment Auxillary Operator & 10.53 & 127 & 422 & 475 & 4.2 & LLD \\
\hline $10-5$ & Auxillary Operator & 11.53 & 33 & 202 & 125 & LLD & LLD \\
\hline $10-5$ & Auxillary Operator & 11.43 & 91 & 311 & 321 & LLD & 1.9 \\
\hline
\end{tabular}

ALower Limit of Detection. The LLO for nickel and cadmium is 3 and 2 uq per sample, respectively. 
APPENDIX VIII

Brick Plant (Bedyard) - Personal Exposures to Metallic Aerosols

Southwire Company, Inc.

Carrollton, Georqia

October 4-5, 1978

\begin{tabular}{|c|c|c|c|c|c|c|c|c|c|}
\hline \multirow[b]{2}{*}{ Date } & \multirow{2}{*}{\multicolumn{3}{|c|}{ Worker }} & \multirow{2}{*}{$\begin{array}{l}\text { Sample Time } \\
\text { Hours }\end{array}$} & \multicolumn{5}{|c|}{ Airborne Concentration $-u \mathrm{~g} / \mathrm{M}^{3}$} \\
\hline & & & & & Lead & Copper & Zinc & Nickel & Cadmium \\
\hline $10-3$ & Press & Brick & Operator & 11.70 & 138 & 664 & 452 & 7.5 & 2.8 \\
\hline $10-3$ & Press & Brick & Operator & 11.58 & 85 & 365 & 307 & LLDA $^{A}$ & LLD \\
\hline $10-4$ & Press & Brick & Operator & 10.73 & 52 & 269 & 163 & 3.1 & I.LD \\
\hline $10-4$ & Press & Brick & Operator & 11.66 & 35 & 218 & 128 & LLD & LLO \\
\hline $10-5$ & Press & Brick & Operator & 11.50 & 46 & 155 & 155 & LLO & LLO \\
\hline $10-5$ & Press & Brick & Operator & 11.45 & 612 & 2330 & 2427 & 17 & 12 \\
\hline $10-5$ & Press & Brick & Operator & 10.98 & 162 & 577 & 577 & 6.1 & 3.0 \\
\hline
\end{tabular}

A Lower Limit of Detection. The LI.D for nickel and cadmium is 3 and 2 ua per sample, respectively. 
DEPARTMENT OF HEALTH AND HUMAN SERVICES

PUBLIC HEALTH SERVICE

CENTEA9 FON DIEKAET CONTROL

NATIONAL INSTITUTE FOR OCCUPATIONAL EAFETY AND HEALTH ROBEAT A. TAFT LABOAATORIES

478 COLlUMBIA PARKWAY, CINCINMATI, OHIO 45226

OFFICIAL BUSINESS

penaltr For private use $\mathbf{0 0 0}$
Third Class Mail

POSTAGE AND FEES PAID

U.S. DEPARTMENT OF HHS

HHS 300 